\title{
Tracking Sandy: Monmouth County Remembers
}

\section{By Melissa Ziobro}

\section{DOI: http://dx.doi.org/10.14713/njs.v5i1.152}

This article is a modified version of the exhibit text used in "Tracking Sandy: Monmouth County Remembers." Guest curated for the Monmouth County Historical Association (MCHA) by the author of this piece, this crowdsourced exhibit was installed in MCHA's headquarters in October 2017. The text is being published in this format to allow distribution to a wider audience/in perpetuity after the exhibit has come down, and to ensure the stories shared for the creation of the exhibit can continue to be told. This is not intended to be a comprehensive history of Sandy's impact globally, in the US, or even on the entire state of New Jersey (NJ) specifically, nor is it a thorough case study on the effectiveness of crowdsourcing community history (though that may be an interesting subject for another discussion). ${ }^{1}$

\section{Introduction}

On October 29, 2016, the Monmouth County Historical Association (MCHA) announced that it would begin to document Superstorm Sandy's impact on the County in advance of a major exhibition to mark the $5^{\text {th }}$ anniversary of the Storm in October $2017 .^{2}$ This would be new territory for the Association, which did not usually interpret $21^{\text {st }}$ century events. Furthermore, the Association had no existing Sandy collection. Unable to pull the photographs, artifacts, and stories it needed from its existing collections, MCHA began the yearlong process of collecting

\footnotetext{
${ }^{1}$ For comprehensive, general histories of Sandy, see Diane C. Bates, Superstorm Sandy: The Inevitable Destruction and Reconstruction of the Jersey Shore (New Brunswick: Rutgers University Press, 2016); Kathryn Miles, Superstorm: Nine Days Inside Hurricane Sandy (New York, New York: Penguin Group, 2014); Adam Sobel, Storm Surge: Hurricane Sandy, Our Changing Climate, and Extreme Weather of the Past and Future (New York, New York: Harper Wave, 2014); Michael J. Tougias, Rescue of the Bounty: Disaster and Survival in Superstorm Sandy (New York, New York: Scribner, 2015). This list is not exhaustive.

${ }^{2}$ Monmouth County Historical Association, "Tracking Sandy: Monmouth County Remembers," accessed 5

December 2018, https://monmouthhistory.org/exhibitions/tracking-sandy-monmouth-county-remembers/.
} 
photographs and artifacts, and conducting oral history interviews, in order to allow all interested parties, from the average Monmouth County citizen, to scientists, to first responders, to the County Freeholders, ${ }^{3}$ to recall the storm in their own words. "Crowdsourcing" material in this way would provide a platform for the people of the County to commemorate the storm on their own terms and allow MCHA to tell a truly unique and "Monmouth-centric" tale.

As the authors of the 2017 text Museums in Motion write, "Crowdsourced content...provide much-needed services to our institutions and can result in deep and sustained engagement among...museum visitors." ${ }^{5}$ For all its merits, though, crowdsourcing poses many challenges. A curator must work with what they get, piecing together information, verifying stories, and identifying gaps as they move towards a cohesive narrative. Over the course of a year, the exhibit team dispersed press releases, harnessed social media, used email lists, hosted open houses, gave interviews, and networked to try to publicize the project. What emerged from these efforts represented just the beginning of MCHA's attempt to create a long-term repository dedicated to the experience of those Monmouth County residents impacted by Sandy from the Coast to the Turnpike, as the collection of stories and artifacts is expected to continue long after the exhibit has come down.

\footnotetext{
${ }^{3}$ As explained on the Monmouth County government's website, "Monmouth County is governed by five Freeholders elected at-large for three year terms." See more on the history of this system of government here. ${ }^{4}$ Tracking Sandy used 17 oral history interviews conducted specifically for the Monmouth County Historical Association. There have been other Hurricane/Superstorm Sandy oral history projects that include Monmouth County stories (though these projects were not focused exclusively on the County, as were the interviews conducted for Tracking Sandy). See, for example, The College of NJ's "Hurricane Sandy Oral History Project" at https://hurricanesandy.pages.tcnj.edu/; Monmouth University’s "Hurricane Sandy Oral History Interviews" at http://library.monmouth.edu/main/content/hurricane-sandy-oral-history-interviews; and Kean University’s “Staring Out to Sea" at http://staringouttosea.com.

${ }^{5}$ Edward Porter Alexander, et al, Museums in Motion: An Introduction to the History and Functions of Museums (New York, New York: Rowman and Littlefield/American Association for State and Local History, 2017). For more on crowdsourcing history, see Barry Lord and Maria Piacente, Manual of Museum Exhibitions (New York, New York: Rowman and Littlefield, 2014); Amy K. Levin and Joshua G. Adair, Defining Memory: Local Museums and the Construction of History in America's Changing Communities (New York, New York: Rowman and Littlefield, 2017); and Mia Ridge, ed., Crowdsourcing our Cultural Heritage (New York, New York: Routledge, 2017).
} 


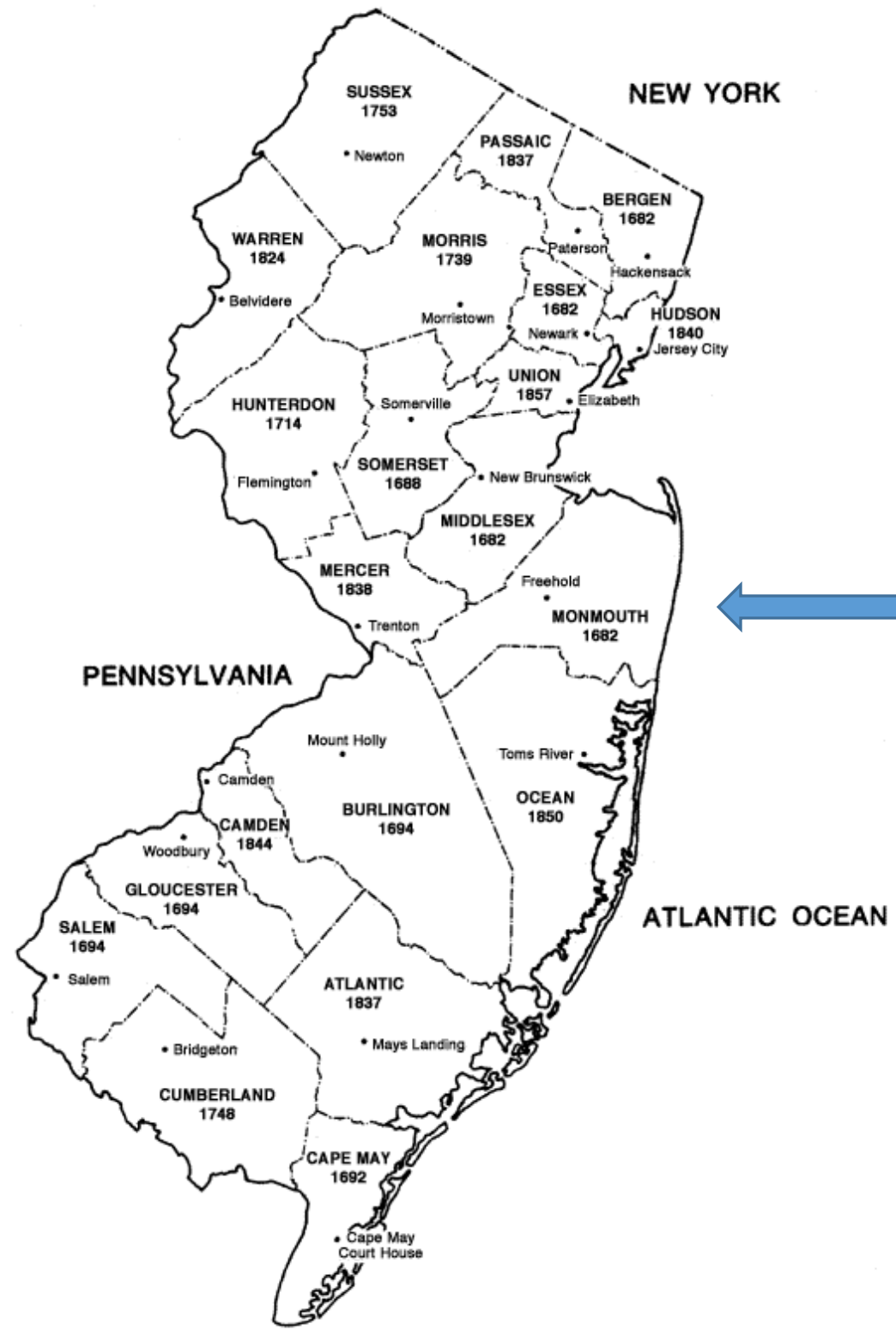

Map courtesy NJ Department of State. Accessed 4 January 2019. In describing Monmouth County, local photographer Michael McLaughlin mused in his July 31, 2017 Tracking Sandy interview, "I've traveled the world, I've traveled the entire country, 47 out of 50 states, and 22 countries, and I keep coming back here. Not just for family, it's- you know I love the ocean, I love the shore, growing up in the area, I went to school on Sandy Hook. You know... in Monmouth County you've got beach, you've got farmland, you've got winding roads and hills... But then you've got the city... not even an hour away. You've got Philly, you've got mountains, you've got skiing. So yeah it's nicely, centrally located to just about everything you could want." 
The exhibit that eventually took shape, called "Tracking Sandy: Monmouth County Remembers," assessed storm preparations, the science behind the storm, the role of first responders, community efforts, rebuilding, and Monmouth County's preparations for future emergencies, weather related or otherwise. Guest-curated by Monmouth University Specialist Professor of Public History Melissa Ziobro and designed by Stan Cain, it opened October 29, 2017 in the Washington Gallery at MCHA's headquarters on 70 Court Street in Freehold. After several extensions, it will be coming down in early 2019.

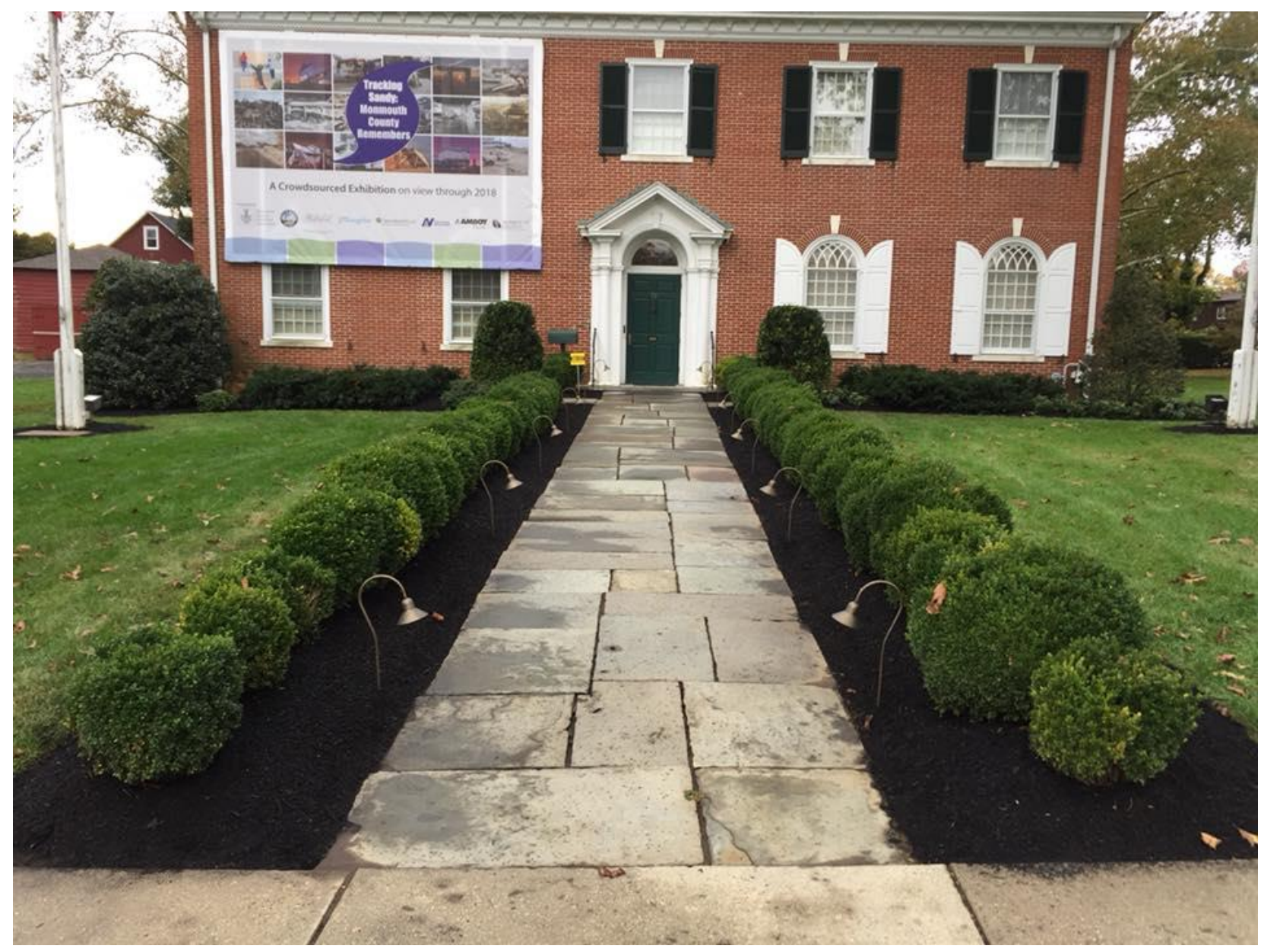

MCHA Headquarters, with Tracking Sandy signage affixed. Author's photograph. 


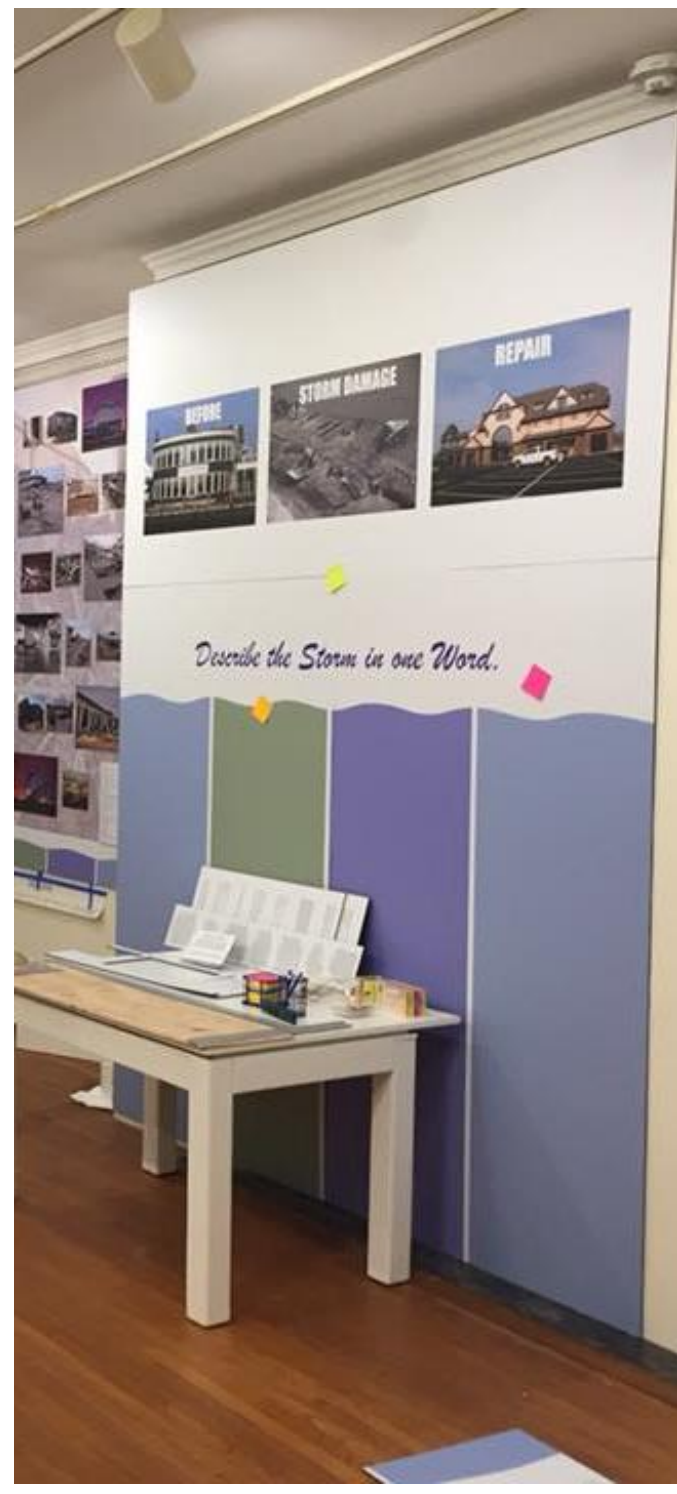

This photograph, taken while the exhibit was still under construction, shows the wall inviting guests to grab a post-it note and describe the Storm in one word. This proved one low-cost way to allow guests to interact with the exhibit. These responses will be archived when the exhibit is removed. Author's photograph.
Visitors were invited to interact with the exhibit in a number of ways, for example sharing the "one word" they would use to describe Sandy, and voting on what they called the Storm (a Hurricane, Superstorm, etc). ${ }^{6}$ Reflection questions posted around the room encouraged guests to stop and ponder things like "Where did you spend the night of the Storm? As it was happening, did you have any idea how bad it was?" Directions explained how to donate photos, artifacts, or stories. Excerpts from oral histories were reproduced on the walls; complete oral histories could be listened to on devices provided, or read in binders. Computer tablets were available so that guests could enter their address and "know their [evacuation] zone," because in addition to learning about the past, the team wanted everyone to leave the exhibit better prepared for the future. ${ }^{7}$

As the exhibit opened five years after the storm, not everyone had rebuilt. Not everyone had recouped financial losses. Not everyone had, mentally and emotionally, recovered. Not everyone was sure what Sandy could teach the community about the

\footnotetext{
${ }^{6}$ See page 13 for photographs of the voting interactive.

${ }^{7}$ Monmouth County Sheriff's Office, "Know Your Zone," accessed 3 December 2018, https://www.mcsonj.org/knowyourzone/; see image page 26.
} 
sustainability of the shore, and climate change, and building codes, and resiliency, and more. Five years later, the people of Monmouth County were still Tracking Sandy's impacts on their lives. So what did they learn when they visited the exhibit?
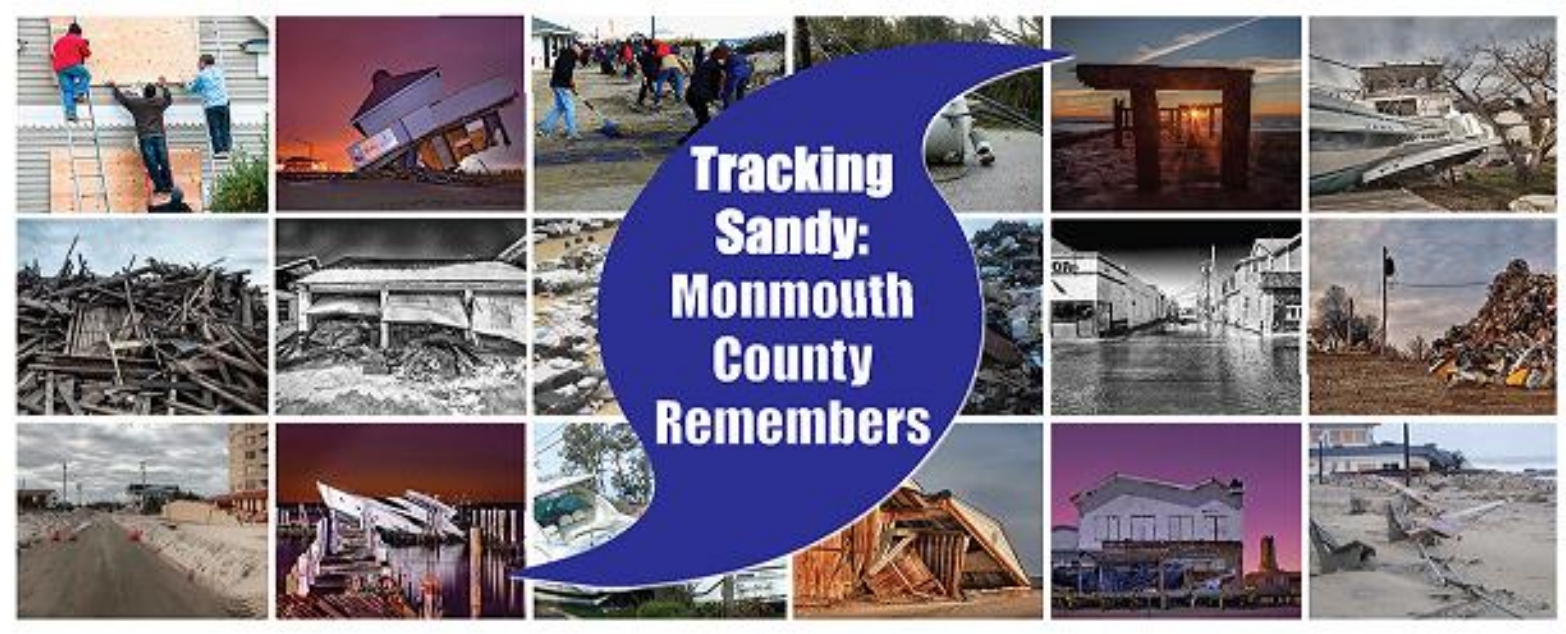

\section{A Crowdsourced Exhibition on view through 2018}

Partial Funding \& Spensership by:
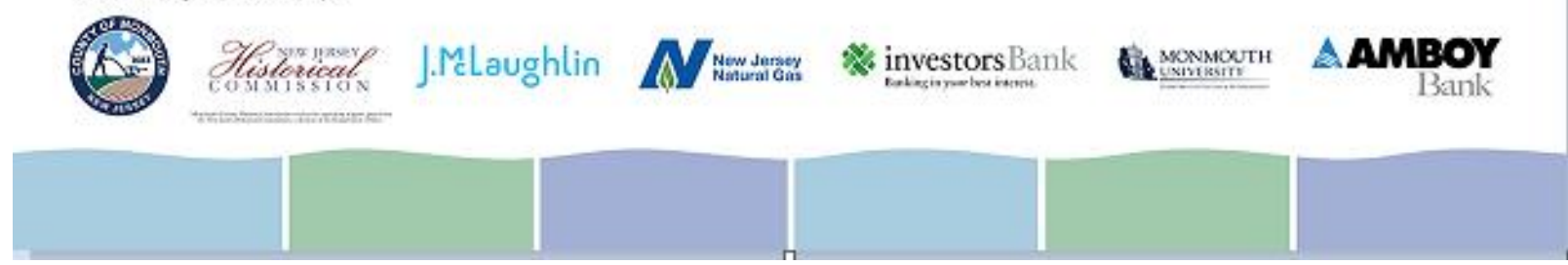

This promotional piece for the exhibit, by exhibit designer Stan Cain, incorporated crowdsourced photographs.

\section{Storm Preparation}

Sandy's origin, according to the National Hurricane Center (NHC), was "primarily associated with a tropical wave that left the west coast of Africa" on October 11, 2012. The wave entered the eastern Caribbean Sea early on October 18. The NHC's Hurricane Sandy Advisory Archive shows Sandy-related warnings issued beginning October 22. These dealt primarily with Jamaica. It was really too far out, at that point, to know what Sandy might mean for the eastern seaboard. Six days before Sandy made it to NJ, a computer program based in England known as 
the European Centre for Medium-range Weather Forecasting (ECMWF) predicted the Storm would make landfall somewhere between NJ and New York City on Monday, October 29. At that point, most of the other models in use at the NHC in Miami, including the US Global Forecast System (GFS), had Sandy veering away from the Atlantic Coast and staying far out at sea. Forecasters showed various models until four days before the storm when the other models came to mirror the ECMWF. Emergency management officials in the northeastern US had days to prepare, issuing evacuation orders for hundreds of thousands of residents. ${ }^{8}$ In NJ, Governor Chris Christie declared a state of emergency on Saturday, October 27 and issued a mandatory evacuation order for the barrier islands, from Monmouth County's Sandy Hook to Cape May, by 4 p.m. on Sunday, October 28. The Monmouth County Office of Emergency Management and the County's Board of Chosen Freeholders issued their own state of emergency for all of Monmouth County, also on the 27. Local communities issued evacuation orders, too. Keep in mind that even in a "mandatory" evacuation, police do not physically remove people from their homes against their will. Those who choose to stay behind, though, are warned that there may be a point at which first responders will be unable to reach them. As Monmouth County Office of Emergency Management Director Mike Oppegaard advised in a press release, "The most important factor we need to stress

\footnotetext{
${ }^{8}$ Linus Magnusson, Jean-Raymond Bidlot, Simon T. K. Lang, Alan Thorpe, Nils Wedi, and Munehiko Yamaguchi, "Evaluation of Medium-Range Forecasts for Hurricane Sandy," Monthly Weather Review (2014) 142 (5): 19621981; Eric S. Blake, Todd B. Kimberlain, Robert J. Berg, John P. Cangialosi and John L. Beven II, "Mitigation Assessment Team Report Hurricane Sandy in NJ and New York Building Performance Observations, Recommendations, and Technical Guidance FEMA P-942," November 2013, http://www.nhc.noaa.gov/data/tcr/AL182012_Sandy.pdf; FEMA Mitigation Assessment Team, "History of Sandy and Hurricanes in the Northeast," November 2013, https://www.fema.gov/media-library-data/13855904662713f96d4791ee402a344cfd070b9e5a476/Sandy MAT AppE 508post.pdf; National Weather Service, "Hurricane Sandy," accessed 6 December 2018, https://www.weather.gov/okx/HurricaneSandy.
} 
throughout this event is that people stay safe... If you need to evacuate, make arrangements with family or friends who live in an area that will be less impacted by the storm."9

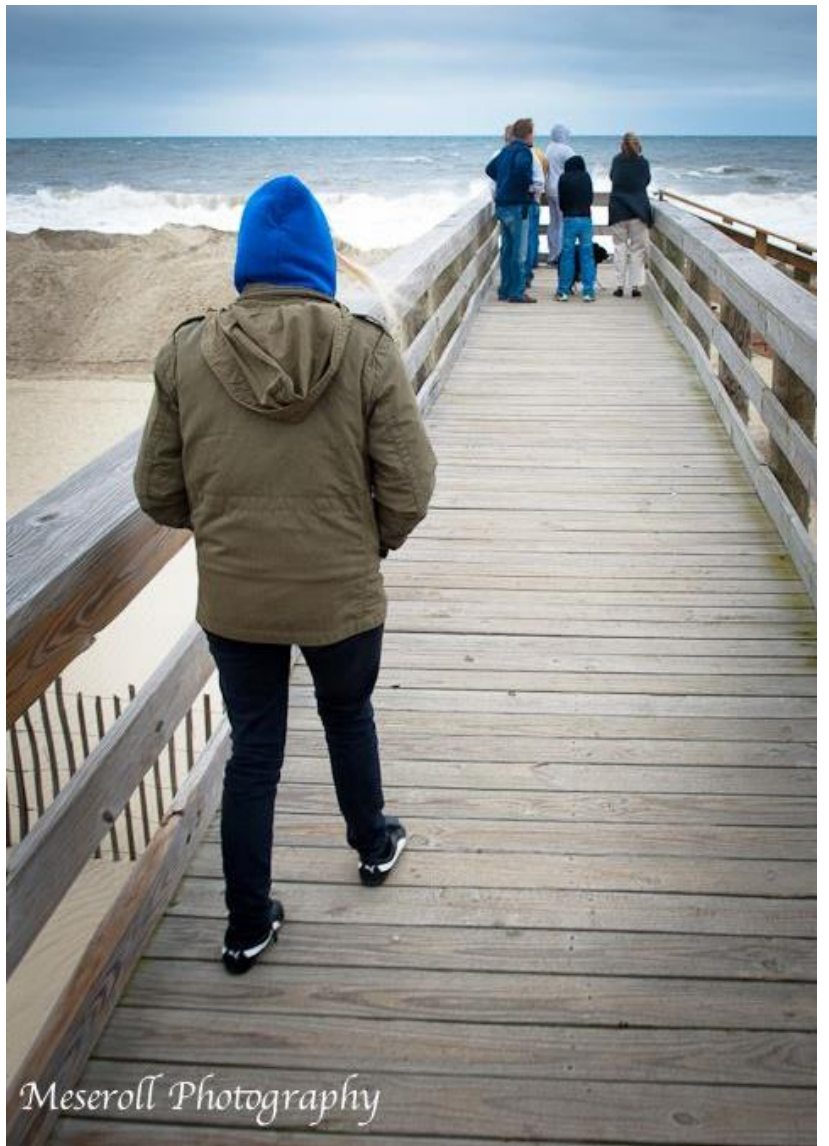

Locals taking advantage of the view from atop the sea wall in Monmouth Beach in advance of the Storm. Photograph courtesy of Monmouth County resident Russ Meseroll.
A February 2013 study conducted by the Monmouth University Polling Institute reported that seven in ten coastal residents $(71 \%)$ surveyed reported that they were either ordered or advised to evacuate before the storm, but only $34 \%$ actually did. Another $7 \%$ left while the storm was underway and $5 \%$ had to leave after the storm passed. ${ }^{10}$ Even those who ignored the evacuation order used the forecasts to make preparations, boarding up buildings, piling sand bags, stocking up on food and water, and buying gasoline-powered generators. ${ }^{11}$ And of course, this being the Jersey Shore, there were those who ran to the beach see the waves... ${ }^{12}$

\footnotetext{
9 "Governor Christie Press Briefing in Monmouth County on Hurricane Sandy," YouTube, 27 October 2012, https://www.youtube.com/watch?v=rMuksUXwZYM; Monmouth County Sheriff's Office, "County Issues State of Emergency,” 27 October 2012, https://www.mcsonj.org/county-issues-state-of-emergency/.

${ }^{10}$ Monmouth University Polling Institute, "Superstorm Sandy Survey: Impact On NJ Coastal Residents," February 2013, https://www.monmouth.edu/pollinginstitute/documents/monmouthpoll_njsandycoast_050713.pdf/.

${ }^{11}$ Contemporary news coverage of Sandy preparations abounds, see for example Jennifer Conic, "Hurricane Sandy: New Jersey shares preparations, early brushes with the storm on social media," NJ.com, 28 October 2012, https://www.nj.com/news/index.ssf/2012/10/hurricane sandy_new_jersey_sha.html.

${ }_{12}$ The phenomenon of Jersey Shore residents flocking to beaches during storms is well documented. As local photographer Mike McLaughlin put it in his Tracking Sandy oral history interview, "I had documented a few storms throughout time with the newspapers, and one of the interesting things about the Jersey Shore and storms is- I would literally, whenever a hurricane was coming in, I would get a call from the Asbury Park Press, or the Star Ledger, or whoever. 'Can you go down to Manasquan, and photograph the people on the beach?' Because, 'oh there's a hurricane coming, let's go down to the beach and check out the waves.' That's the mentality at the Jersey Shore. ...Yeah, Jersey Shore people are kind of nuts. Those guys are like, 'Oh this is good surfing.' [Laughter] Sandy was
} 


\section{The Science Behind Sandy}

Sandy was the $18^{\text {th }}$ named tropical cyclone of the 2012 Atlantic hurricane season. ${ }^{13}$ The Storm "formed in the central Caribbean on October 22 and intensified into a hurricane as it tracked north" towards Jamaica. ${ }^{14}$ It made landfall as a category 1 hurricane in Jamaica on October 24 and peaked near a category 3 hurricane in eastern Cuba on October 25. Sandy weakened to a category 1 hurricane while moving through the Bahamas over the course of October $25-26,{ }^{15}$ but "grew considerably in size" despite weakening further into a tropical storm north of those islands. The system strengthened again into a hurricane while it moved northeastward, "parallel to the coast of the southeastern United States (US)." It is not unusual for a hurricane to strengthen and weaken, and weaken and strengthen in this way. ${ }^{16}$

Meteorologists, politicians, and millions of Americans in her path watched and waited to see if Sandy would turn out to sea, as some forecasting models had predicted (and hurricanes often do). Or would she would make a less typical left-hand turn, straight into the Eastern Seaboard? She gained speed and did indeed turn northwestward toward the mid-Atlantic states. As Tony MacDonald, Director of Monmouth University's Urban Coast Institute noted in his Tracking Sandy oral history interview, “... it really took a very unusual and dramatic left hand turn as it

the one that woke everyone up to go, you know, 'holy shit, this is ... yeah maybe we should start taking this a little more seriously.' Sadly so, but yeah."

${ }^{13}$ Astute readers might notice that ' $\mathrm{S}$ ' is not the $18^{\text {th }}$ letter of the alphabet. The letter ' $\mathrm{Q}$ ' is not used. "Hurricane Sandy," National Weather Service, accessed 6 December 2018, https://www.weather.gov/okx/HurricaneSandy. ${ }^{14}$ Ibid.

${ }^{15}$ National Oceanic and Atmospheric Administration, "Service Assessment: Hurricane/Post-Tropical Cyclone Sandy October 22-29, 2012," May 2013, https://www.weather.gov/media/publications/assessments/Sandy13.pdf; FEMA Mitigation Assessment Team, "History of Sandy and Hurricanes in the Northeast," November 2013, https://www.fema.gov/media-library-data/13855904662713f96d4791ee402a344cfd070b9e5a476/Sandy_MAT_AppE_508post.pdf.

${ }^{16}$ FEMA Mitigation Assessment Team, "History of Sandy and Hurricanes in the Northeast," November 2013, https://www.fema.gov/media-library-data/1385590466271$\underline{\text { 3f96d4791ee402a344cfd070b9e5a476/Sandy MAT_AppE 508post.pdf. }}$ 
came up the coast." 17 The track of Hurricane Sandy was indeed unusual for an East Coast storm.

Since 1870 , only one other hurricane has made a direct landfall in NJ without previously encountering land, such as the Carolinas. All other hurricane tracks "have paralleled the coastline."18

Sandy weakened somewhat in wind speed before making landfall as a post-tropical cyclone near Atlantic City, NJ at approximately 8pm on Monday, October 29. Though not technically a category 1 hurricane at this point, the storm's atmospheric pressure was the lowest ever reported in the US north of North Carolina. It covered about 1,000 miles when it hit NJ, roughly three times the area covered by Hurricane Katrina in Louisiana in 2005. Due to a variety of factors including this historic low pressure and her tremendous size, Sandy drove a "catastrophic" storm surge into the NJ and New York coastlines. Monmouth County saw record-breaking storm surges in excess of 13 feet in some places. ${ }^{19}$

Though it is difficult to quantify, the Federal Emergency Management Agency (FEMA) estimated total economic losses across the US from Hurricane Sandy at $\$ 50-65$ billion, making

\footnotetext{
${ }^{17}$ Oral history interview with Tony MacDonald, interviewed by Melissa Ziobro, West Long Branch, NJ, 10 July 2017, property of the Monmouth County Historical Association; Andy Mussoline, "How Sandy Exploded Into a Superstorm One Year Ago," 1 November 2013, https://www.accuweather.com/en/weather-news/superstorm-sandyjersey-1/19381306.

${ }^{18}$ Eric S. Blake, Todd B. Kimberlain, Robert J. Berg, John P. Cangialosi and John L. Beven II, "Mitigation Assessment Team Report Hurricane Sandy in NJ and New York Building Performance Observations, Recommendations, and Technical Guidance FEMA P-942," November 2013, http://www.nhc.noaa.gov/data/tcr/AL182012 Sandy.pdf; FEMA Mitigation Assessment Team, "History of Sandy and Hurricanes in the Northeast," November 2013, https://www.fema.gov/media-library-data/13855904662713f96d4791ee402a344cfd070b9e5a476/Sandy_MAT_AppE_508post.pdf.

${ }^{19}$ Andrew Freedman, "NWS Confirms Sandy Was Not a Hurricane At Landfall," Climate Central, 12 February 2013, http://www.climatecentral.org/news/nws-confirms-sandy-was-not-a-hurricane-at-landfall-15589; Thomas J. Gaalarneau, Christopher A. Davis, and Melvyn A. Shapiro, "Intensification of Hurricane Sandy (2012) through Extratropical Warm Core Seclusion," Monthly Weather Review (2013) 141 (12): 4296-4321; Pascack Valley Learning Center, Surviving Sandy: The Superstorm That Reshaped Our Lives (New York, New York: Ambient Funding, 2013), 108; FEMA Mitigation Assessment Team, "History of Sandy and Hurricanes in the Northeast," 3 December 2018, https://www.fema.gov/media-library-data/13855904662713f96d4791ee402a344cfd070b9e5a476/Sandy_MAT_AppE_508post.pdf.
} 
Sandy one of the costliest storms to ever hit the country. ${ }^{20}$ There were at least 147 direct deaths recorded across the Atlantic basin due to Sandy, with 72 of these fatalities occurring in the midAtlantic and northeastern US. This represented the greatest number of US direct fatalities related to a tropical cyclone outside of the southern states since Hurricane Agnes in 1972. ${ }^{21}$

The total economic impact to NJ was estimated by the Governor's Office at the time to be about $\$ 30$ billion. ${ }^{22}$ While several dozen people in $\mathrm{NJ}$ lost their lives as a result of the storm, ${ }^{23}$ fortunately, there were no deaths directly related to Sandy in Monmouth County. As Monmouth County Sheriff Shaun Golden recalled in his Tracking Sandy oral history interview, "in Monmouth County, we had zero loss of life. Again, I think that was because of our constant messaging about evacuation, our ability of messaging and education for preparing and knowing where you live and being able to react accordingly." ${ }^{24}$ And as then-Freeholder Serena DiMaso noted in her Tracking Sandy oral history interview, "in the end it was just personal belongings that were lost. We really were very lucky here in Monmouth," comparatively speaking. ${ }^{25}$

\section{What's in a Name?}

\footnotetext{
${ }^{20}$ FEMA Mitigation Assessment Team, "History of Sandy and Hurricanes in the Northeast," November 2013, https://www.fema.gov/media-library-data/13855904662713f96d4791ee402a344cfd070b9e5a476/Sandy MAT_AppE 508post.pdf; Asbury Park Press, Sandy: The Jersey Shore in the Eye of the Storm (Battle Ground, Washington: Pediment Publishing, 2012), 6.

${ }^{21}$ FEMA Mitigation Assessment Team, "History of Sandy and Hurricanes in the Northeast," https://www.fema.gov/media-library-data/13855904662713f96d4791ee402a344cfd070b9e5a476/Sandy_MAT_AppE_508post.pdf; Eric S. Blake, Todd B. Kimberlain, Robert J. Berg, John P. Cangialosi and John L. Beven II, "Mitigation Assessment Team Report Hurricane Sandy in NJ and New York Building Performance Observations, Recommendations, and Technical Guidance FEMA P-942," November 2013, http://www.nhc.noaa.gov/data/tcr/AL182012_Sandy.pdf;

${ }^{22}$ Chris Francescani, "NJ Governor estimates Sandy will cost state at least \$29.4 billion,” 23 November 2012 , https:/www.reuters.com/article/us-storm-sandy-costestimate/nj-governor-estimates-sandy-will-cost-state-at-least29-4-billion-idUSBRE8AN01920121124.

${ }^{23}$ Counting storm-related deaths can be extremely emotionally charged. A 2013 report by the Center for Disease Control puts the number of Sandy-related deaths in NJ at 24, see https://www.cdc.gov/mmwr/preview/mmwrhtml/mm6220a1.htm. News outlets have put the number at 40 or slightly over.

${ }^{24}$ Oral history interview with Shaun Golden, interviewed by Melissa Ziobro, Freehold, NJ, 1 August 2017, property of the Monmouth County Historical Association.

${ }^{25}$ Oral history interview with Serena DiMaso, interviewed by Melissa Ziobro, Freehold, NJ, 29 August 2017, property of the Monmouth County Historical Association.
} 
Hurricane. Frankenstorm. Superstorm. Different people have called Sandy different things at different times. Why? The NHC defines a "tropical cyclone" as a "rotating, organized system of clouds and thunderstorms that originates over tropical or subtropical waters and has a closed low-level circulation." Tropical cyclones rotate counterclockwise in the Northern Hemisphere. They are classified as follows, in the words of the NHC:

Tropical Depression: A tropical cyclone with maximum sustained winds of $38 \mathrm{mph}$ (33 knots) or less.

Tropical Storm: A tropical cyclone with maximum sustained winds of 39 to $73 \mathrm{mph}$ (34 to 63 knots).

Hurricane: A tropical cyclone with maximum sustained winds of 74 mph (64 knots) or higher. In the western North Pacific, hurricanes are called typhoons; similar storms in the Indian Ocean and South Pacific Ocean are called cyclones.

Major Hurricane: A tropical cyclone with maximum sustained winds of $111 \mathrm{mph}$ (96 knots) or higher, corresponding to a Category 3, 4, or 5 on the Saffir-Simpson Hurricane Wind Scale. ${ }^{26}$

While laypeople often allow the Saffir-Simpson Hurricane Wind Scale to dictate their understanding of how "bad" a storm will be, this can be misleading as the Scale does not take into account rainfall or storm surge that can lead to catastrophic flooding. (And, according to the NHC, storm surge is often the greatest threat to life and property from a hurricane. Storm surge is "an abnormal rise of water generated by a storm, over and above the predicted astronomical tides." $)^{27}$ As far as the scientific community is concerned, Dr. Rick Knabb, past Director of the NHC, has explained Sandy's classification this way: "While Sandy appeared to almost everyone to be a hurricane, the fact is, by definition, just before landfall [in $\mathrm{NJ}$ ], the storm lost its tropical characteristics. It no longer had a warm core, but rather took on the make-up of a traditional winterstyle storm" when it encountered cold air. Therefore, the NHC stopped referring to it as a Hurricane

\footnotetext{
${ }^{26}$ National Hurricane Center, "Tropical Cyclone Climatology," accessed 6 December 2018, https://www.nhc.noaa.gov/climo/.

${ }^{27}$ National Hurricane Center, "Storm Surge Overview," accessed 6 December 2018 , https://www.nhc.noaa.gov/surge/.
} 
on and off as it tracked through the Caribbean and up the Atlantic. Retired US Army Lieutenant General Russel Honore, the man in charge during the confusing days after Hurricane Katrina flooded much of South Louisiana, scoffed at this technicality, and was quoted as saying, "It boils down to what the common person thinks, you have to put in terms your grandmother can understand. If you tell her a storm is coming ashore, she may not do a thing. If you tell her a hurricane is coming, she'll react differently. That key word -hurricane- causes people to act." Dr. Knabb acknowledged that the NHC struggled with what to call Sandy, but argues that even if his agency would have issued hurricane warnings, he doubts anyone would have acted any differently. He said he was concerned that if hurricane warnings had been issued, and then the storm weakened, that even more confusion would have occurred. Knabb also feared that if forecasters simply "faked it," and called Sandy a hurricane even at times that it technically was not, the Weather Service's scientific credibility would have been scrutinized in the future. ${ }^{28}$

The NHC's declaration that Sandy became a "post-tropical storm" just before it made landfall ultimately provided cost savings to homeowners along the northeast coast (including many in Monmouth County). Although Sandy was designated a hurricane for the majority of its existence, it failed to sustain hurricane-force winds at landfall, so it was officially a tropical storm in NJ. To assist those affected by Sandy, state officials from NJ, New York, Connecticut, and Maryland took action to prohibit insurance companies from imposing the costly hurricane deductibles on homeowners with claims. ${ }^{29}$ For Governor Chris Christie's part, he issued Executive Order 107, which reads in part “In light of the National Weather Service's categorization of Sandy

\footnotetext{
${ }^{28}$ Al Conklin, "What's in a name? Sandy: Hurricane or Superstorm?," WBTV.com, 27 March 2013, http://www.wsfa.com/story/21807734/whats-in-a-name-sandy-hurricane-or-superstorm; Andrew Freedman, "NWS Confirms Sandy Was Not a Hurricane At Landfall," Climate Central, 12 February 2013, http://www.climatecentral.org/news/nws-confirms-sandy-was-not-a-hurricane-at-landfall-15589.

${ }^{29}$ Andrea Pelletier, "Hurricane Sandy VS. Super Storm Sandy: A Tale of Two Deductibles," Gulfshore Insurance, accessed 5 December 2018, http://www.gulfshoreinsurance.com/hurricane-sandy-vs-super-storm-sandy-a-tale-oftwo-deductibles/
} 
as a post-tropical storm, it shall be a violation of N.J.A.C. 11:2-42.7 for any insurer to apply a mandatory or optional hurricane deductible to the payment of claims for property damage attributable to Sandy."30

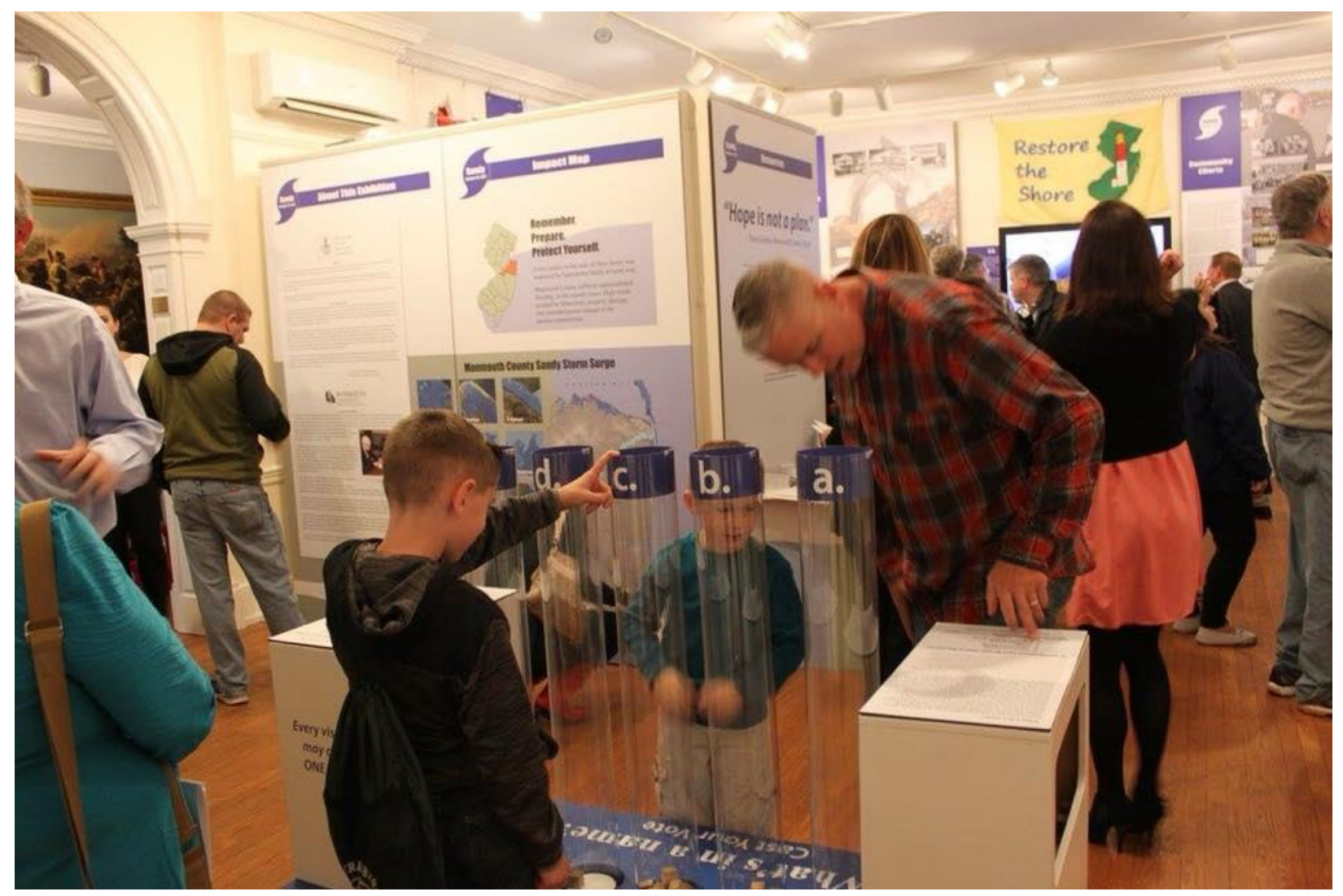

While the exhibit explained that, in NJ, Sandy was technically a Superstorm, the exhibit team wanted to informally poll what visitors called the Storm. An interactive station asked guests, "In conversation, how do you refer to the Storm?" They could vote a. "Hurricane Sandy;" b. "Superstorm Sandy;" c. Just "Sandy;" d. Something else; e. It doesn't matter to me. They cast votes using scraps of salvaged boardwalk wood collected by local artist Cory Hudson following the Storm. Results will be archived when the exhibit is removed. Author's photograph.

\section{Riding It Out}

The US Census Bureau puts the population of Monmouth County at 629,037 in 2012. Most Monmouth County residents, particularly those not located near the coast, bays, rivers, or other

\footnotetext{
30 “Executive Order 107," NJ.gov, accessed 5 December 2018, https://www.nj.gov/infobank/circular/eocc107.pdf.
} 
waterways, rode out the Storm in their homes. Many lost power for an extended period of time. Jim Foley of Oakhurst remembered, "We lost power probably about 5, 5:30 in the afternoon. So we basically had no idea of what was happening... It was definitely a scary night." 31 Approximately 104,000 Monmouth County homes were evacuated, with residents going to stay with family or friends, or in hotels or shelters. The primary shelters organized by the County, which accommodated roughly 2,000 residents, operated at Monmouth University's Multipurpose Activity Center in West Long Branch and the Arthur Brisbane Child Treatment Center in Wall Township. As Serena DiMaso recalled in her Tracking Sandy oral history interview, "at the shelters it was crowded to say the least. Hot. Monmouth University was terrific in letting us use their- we just pretty much took over their whole place. We had to cancel classes because there was just nowhere to put students. As sad as it was, it was heartwarming to see so many wonderful people come together to help their neighbor." 32 The Brisbane facility allowed pets- a need that had become apparent after Hurricane Irene struck the state in August 2011. These shelters would eventually be visited by local, county, state, and federal officials, to include Homeland Security Secretary Janet Napolitano. ${ }^{33}$ Some residents near the coast and other waterways stayed behind, either because they were not under evacuation orders or because they chose not to evacuate for a variety of reasons, such as nowhere to go, no way to get there, mistrust of forecasters, or a desire to try to protect their property in any way they could.

\footnotetext{
${ }^{31}$ Oral history interview with Jim Foley, interviewed by Melissa Ziobro, Long Branch, NJ, 8 August 2017, property of the Monmouth County Historical Association.

${ }^{32}$ Oral history interview with Serena DiMaso, interviewed by Melissa Ziobro, Freehold, NJ, 29 August 2017, property of the Monmouth County Historical Association.

${ }^{33}$ Pascack Valley Learning Center, Surviving Sandy: The Superstorm That Reshaped Our Lives (New York, New York: Ambient Funding, 2013), 108; Oral history interview with Shaun Golden, interviewed by Melissa Ziobro, Freehold, NJ, 1 August 2017, property of the Monmouth County Historical Association.
} 


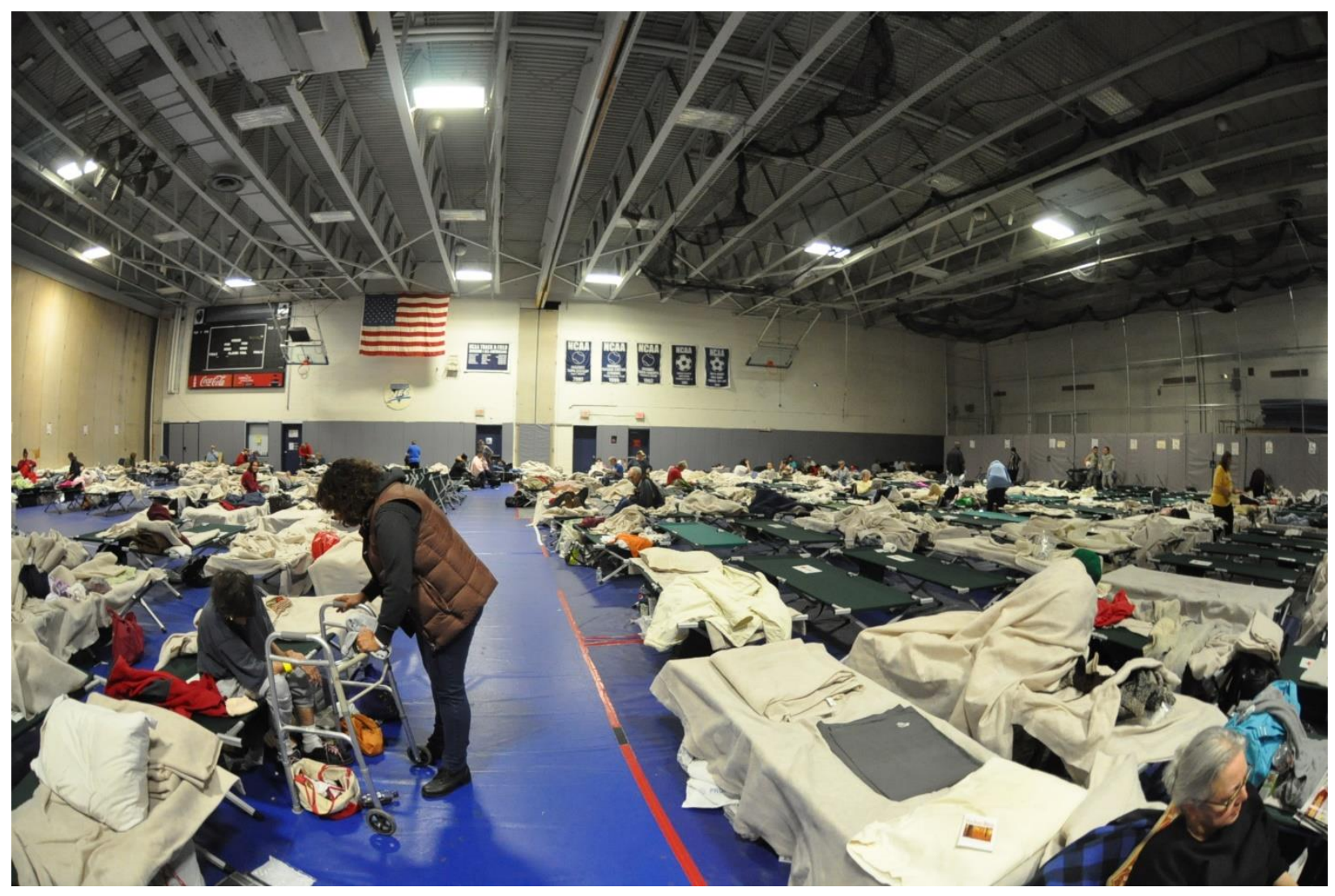

Shelter at Monmouth University, 2 November 2012. Photograph courtesy Jim Reme/Monmouth University.

Many used social media to try to stay informed. As Dr. Amy Williams, Stevens Institute of Technology’s NJ Sea Grant Consortium Coastal Ecosystems Extension Agent, recalled in her Tracking Sandy interview, "So I was sitting there on the cell phone pretty much all night, waking up every hour or two just looking at Facebook and seeing what people are posting." 34 The problem was that nearly half of the state's cell phone users (47\%) reported having signal reception problems following the storm, including $34 \%$ who say these problems lasted for two days or more. A majority of Sprint (71\%), T-Mobile (59\%), and AT\&T (58\%) customers reported experiencing reception problems after the storm. This compares to just $34 \%$ of Verizon customers who say the

\footnotetext{
${ }^{34}$ Oral history interview with Dr. Amy Williams, interviewed by Melissa Ziobro, Manchester, NJ, 21 August 2017, property of the Monmouth County Historical Association. For more on the impact of social media before, during, and after Sandy, see Kryvasheyeu, Yuri, Haohui Chen, Esteban Moro, Pascal Van Hentenryck, and Manuel Cebrian. "Performance of Social Network Sensors during Hurricane Sandy" PloS One (2015) 10, no. 2.
} 
same. Further complicating the matter was the fact that cell phone batteries were difficult to charge during periods of prolonged power outages. ${ }^{35}$

\section{First Responders and the Storm}

First responders such as law enforcement officers, firefighters, and emergency medical technicians worked round the clock before, during, and after Sandy to protect lives and property. Many of these individuals, some volunteers, put themselves at great personal risk in order to do so. They left their families and their property behind in order to fulfill their commitment to the people of Monmouth County. Freeholder Lillian Burry applauded their efforts in her Tracking Sandy oral history interview, saying "we had personnel...working...day and night, who had lost their own homes. It was really quite remarkable."36 Tom Arnone, in his Tracking Sandy interview, agreed, saying, "I can't say enough about our emergency services here in Monmouth County...They're out eight, ten, twelve hours. But they're not home with their families. So that's dedication and a commitment that they make...And if we didn't have that commitment from individuals like that, I don't know where we would've been at that time.”37

As Monmouth County Office of Emergency Management Coordinator Michael Oppegaard recalled in the 2013 book Surviving Sandy, the Monmouth County Emergency Operations Center (EOC) in Freehold was running by 9am on Sunday, October 28 and fully staffed by more than 60 people from various County departments and agencies. They were joined by a 20-person Incident Management Team from Mississippi, which arrived as requested to lend their expertise. At the height of the Storm, the Monmouth County Sheriff's 9-1-1 Communications Center received some

\footnotetext{
${ }^{35}$ Monmouth University Polling Institute, "Sandy’s Impact on NJ," 10 December 2012, https://www.monmouth.edu/polling-institute/reports/monmouthpoll_nj_121012/.

${ }^{36}$ Oral history interview with Lillian Burry, interviewed by Melissa Ziobro, Freehold, NJ, 29 August 2017, property of the Monmouth County Historical Association.

${ }^{37}$ Oral history interview with Tom Arnone, interviewed by Melissa Ziobro, Freehold, NJ, 29 August 2017, property of the Monmouth County Historical Association.
} 
700 rescue calls, with several more requests for assistance coming into the EOC from towns along the coast. Throughout Monday night and into Tuesday morning, the Monmouth County OEM personnel performed over 200 rescues using high-wheeled vehicles, boats, and even scuba divers. ${ }^{38}$

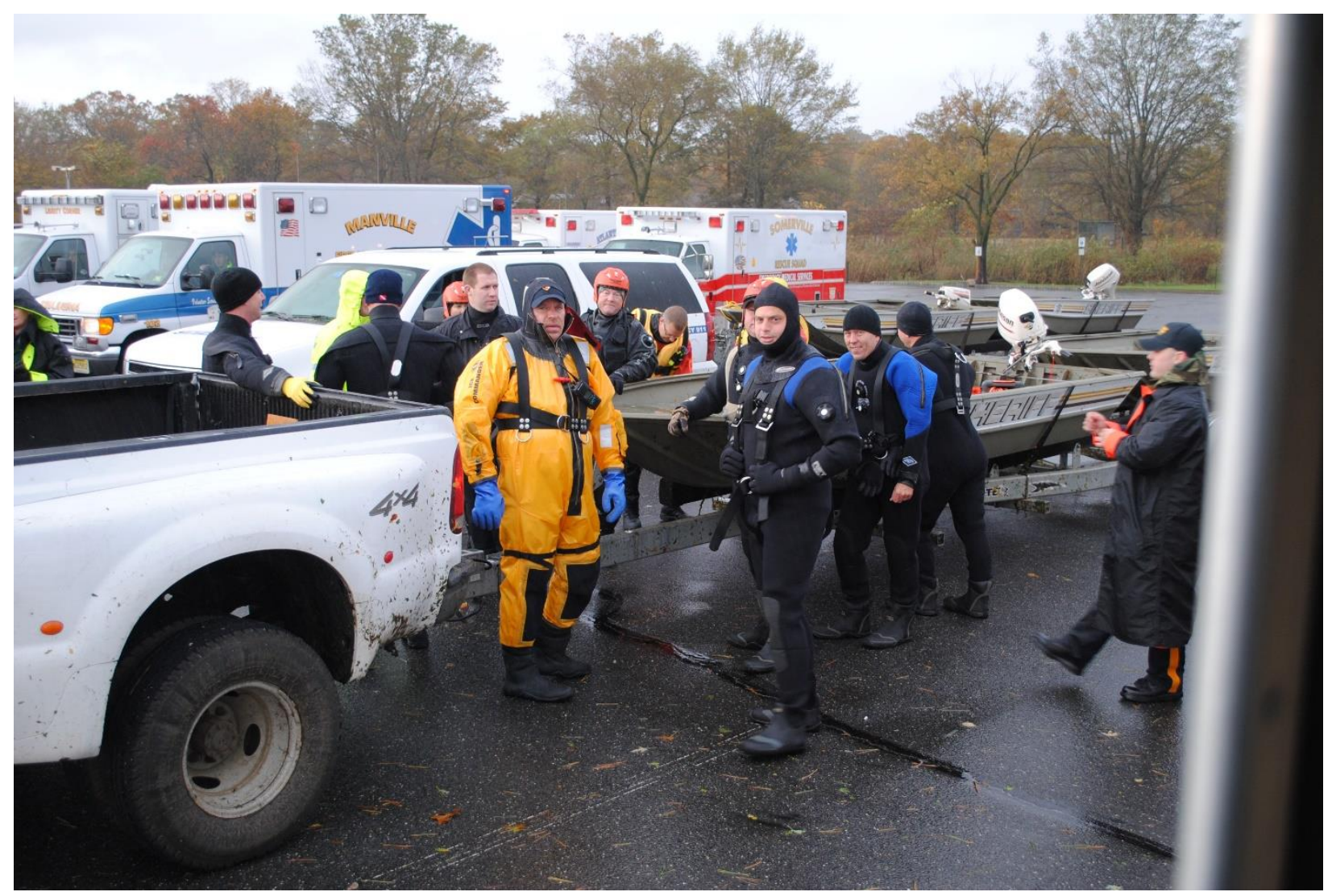

Sheriff's Office divers during Sandy. Photograph courtesy Cynthia Scott/Monmouth County Sheriff's Office.

NJ State Police and law enforcement officers from around the country augmented municipal and Monmouth County forces in the days and weeks after the Storm. Most out of state law enforcement reported to Joint Base McGuire-Dix-Lakehurst for swearing-in ceremonies that would allow them to work in NJ. Their assignments included security at checkpoints and patrols. Governor Christie noted in a press release, "When Hurricanes Katrina and Andrew struck, many

\footnotetext{
${ }^{38}$ Shaun Golden, Cynthia Scott, Mike Oppegaard, and Ted Freeman, "Monmouth County Sheriff's Office Response to Superstorm Sandy," Sheriff (2013) 65 (3): 41-45; Surviving Sandy: The Superstorm That Reshaped Our Lives (New York: Ambient Funding, 2013), 108.
} 
NJ officers selflessly helped with the rescue and recovery efforts... Now we have come full circle in our mutual support and service, with large contingents of officers coming here...we thank every single one of them. This is a proud moment for law enforcement, and another example of how people from across the country are seeing the devastation wrought by the storm, coming together, and helping our state and region pull together through this period of recovery." 39

Roughly 2,500 Soldiers and Airmen of the NJ National Guard participated in recovery efforts as well, rescuing more than 7,000 people and their pets across a 150-mile swath of the state. Their efforts later included clearing more than 300 miles of debris from power lines, delivering more than 25,000 meals and preparing at least that many more in two Mobile Kitchen Trailers. Guardlife quoted Brigadier General James J. Grant as saying that perhaps the greatest contribution made by the individual Soldiers and Airmen, though, was their compassion for their follow citizens and the sense of order they brought to every place they deployed. ${ }^{40}$

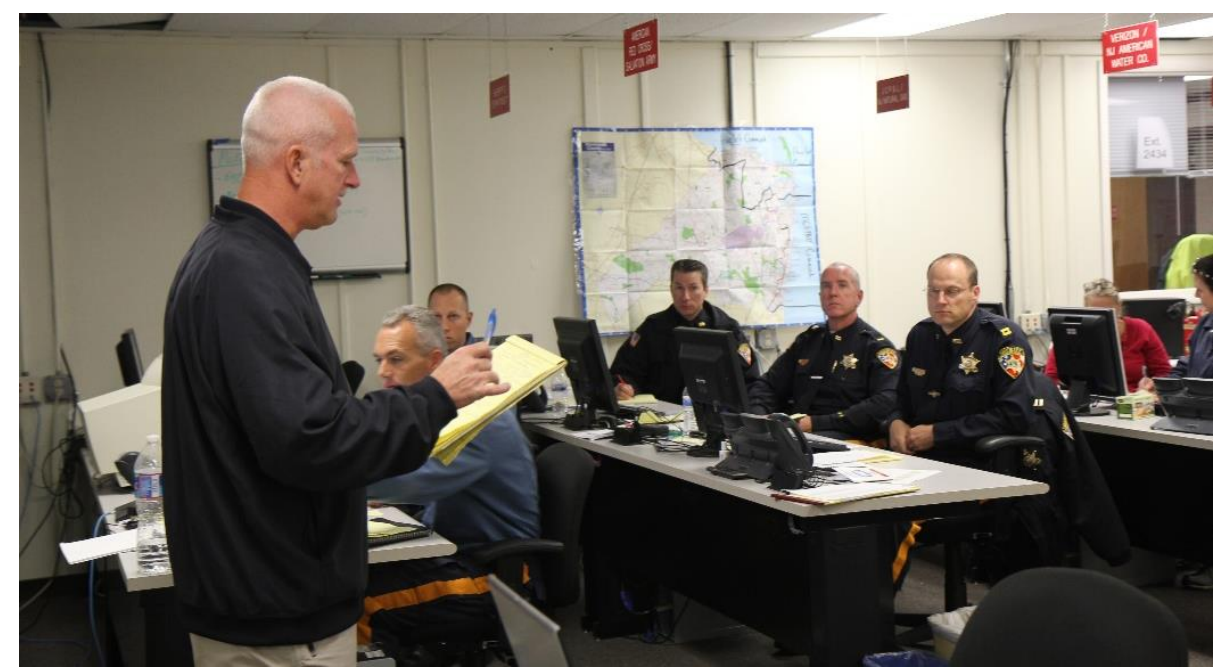

Then Deputy Office of Emergency Management Director Kevin Stout briefs law enforcement at the Monmouth County Emergency Operations Center during Sandy. Photograph courtesy of Cynthia Scott/Monmouth County Sheriffs' Office.

\footnotetext{
${ }^{39}$ NJ State Police Official News Release, "Troopers from Eight States Travel to NJ to Assist Law Enforcement," 5 November 2012, https://www.njsp.org/news/pr110512a.html.

${ }^{40}$ Wayne Woolley, "A Storm - and Response - Unlike Any Other," Guardlife, 35 (4)

https://www.nj.gov/military/publications/guardlife/volume35no4/5.html.
} 


\section{The Immediate Aftermath}

Sandy's storm surge, in addition to large and battering waves, devastated large portions of the coasts of NJ and New York. In fact, the extent of catastrophic damage along the NJ coast was unprecedented in the state's history, with the brunt of it occurring in Monmouth County and its neighbor, Ocean County. Whole communities were inundated by water and sand, houses were washed from their foundations, boardwalks were dismantled or destroyed, cars were tossed about, and boats were pushed well inland from the coast. ${ }^{41}$

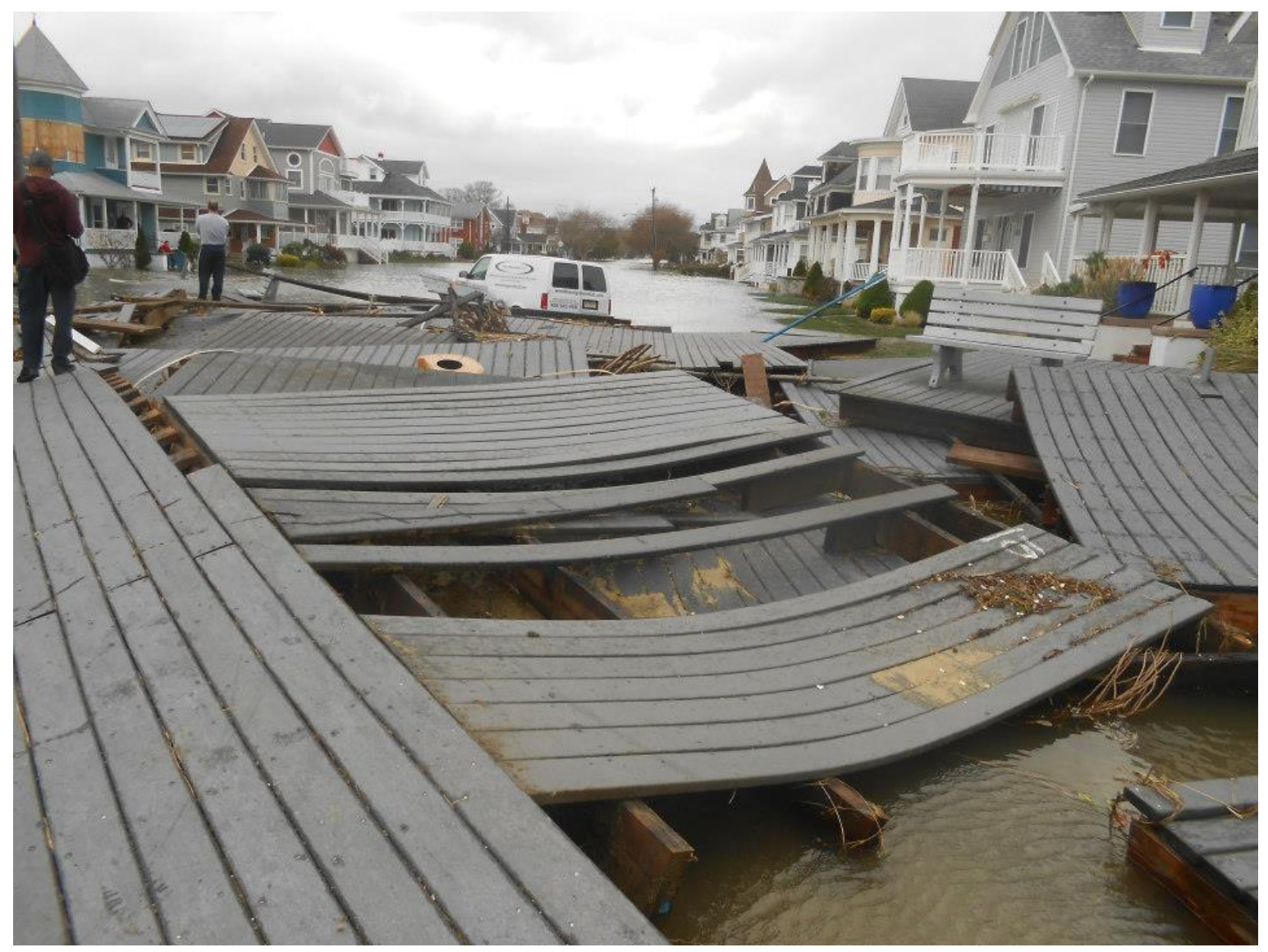

Tossed boardwalk and swamped van at Ocean Avenue and 8th Avenue, Belmar. Photograph courtesy of Monmouth County resident Jenna Amore Wheeler.

\footnotetext{
${ }^{41}$ Susan K. Livio and Jeanette Rundquist, "Hurricane Sandy leaves total devastation in Monmouth County," The Star-Ledger, 1 November 2012; Colleen O'Dea "Interactive Map: Assessing Damage from Superstorm Sandy," NJ Spotlight: News, Issues, and Insight for NJ, 15 March 2013. http://www.njspotlight.com/stories/13/03/14/assessing_damage-from-superstorm-sandy/.
} 
"Ann" from Port Monmouth, whose home was inundated by flood waters and who wishes to remain anonymous, recalled in her Tracking Sandy interview, "we were told to evacuate, but we still didn't imagine the way it happened. We figured when we came back there would be a house and everything would be normal, but it wasn't...it was just like a war zone. Everything all over." 42

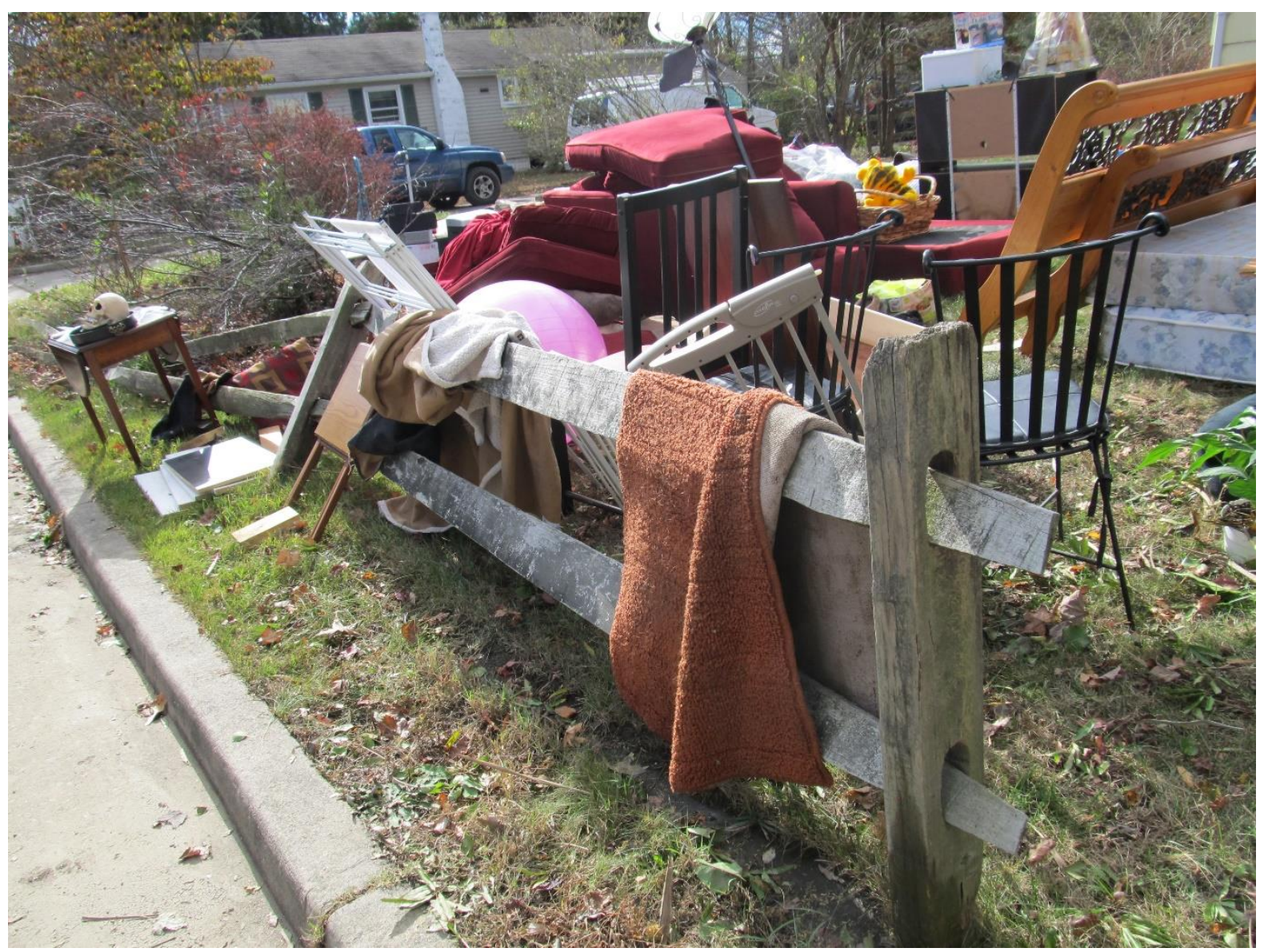

Household items at the curb. Photograph courtesy of Monmouth County resident "Ann."

Freeholder John Curley recalled in his Tracking Sandy oral history interview, "I'll never forget seeing half a house standing there... it was literally half gone. I'll never forget too riding through and there was a ranch style house, and there was a stoop, a porch on the front, a small

\footnotetext{
${ }^{42}$ Oral history interview with "Ann," interviewed by Melissa Ziobro, Port Monmouth, NJ, 28 September 2017, property of the Monmouth County Historical Association.
} 
porch, and there were sandbags in front of the front door, what had been a front door. The entire house was gone. The foundation remained partially, but that porch was still there with those sandbags still placed where they were originally put. That was surreal, because that looked like something out of an Alfred Hitchcock movie." In another instance, Curley says, "I had gone to Sea Bright, and I remember the road was plowed and probably 12 to 15 feet of sand on either side of the road...The most surreal thing was boats that had floated right on through the house, but they went through the second story of the house, because the water had gone up that high. That was truly surreal."43 Monmouth County photographer Mike McLaughlin recalled, "Union Beach especially was just unreal... I don't even know how to describe what I saw..." ${ }^{44}$ Joe Barris of the Monmouth County Office of Planning lamented in his Tracking Sandy interview, “... growing up down the shore and watching things destroyed from your childhood... It's an emotional thing."45 The NJ Governor's office estimated that roughly 346,000 housing units were damaged or destroyed in the state, with 22,000 of those units uninhabitable. Severe damage to businesses occurred in NJ, with nearly 19,000 businesses sustaining damage of $\$ 250,000$ or more, and total business losses estimated at $\$ 8.3$ billion. $^{46}$

\footnotetext{
${ }^{43}$ Oral history interview with John Curley, interviewed by Melissa Ziobro, Freehold, NJ, 29 August 2017, property of the Monmouth County Historical Association.

${ }^{44}$ Oral history interview with Mike McLaughlin, interviewed by Melissa Ziobro, Matawan, NJ, 31 July 2017, property of the Monmouth County Historical Association.

${ }^{45}$ Oral history interview with Joe Barris, interviewed by Melissa Ziobro, Freehold, NJ, 18 July 2017, property of the Monmouth County Historical Association.

${ }^{46}$ Dr. Raghuveer Vinukollu, "Risk and Reinsurance," April 2017, https://www.state.nj.us/dep/aqes/docs/4417rnr.pdf; Nancy H. Mantell, et al, "The economic and fiscal impacts of Hurricane Sandy in New Jersey, a macroeconomic analysis," Rutgers Regional Report 34, 1-16. Retrieved from doi:10.7282/T3Q81B9X; Asbury Park Press, Sandy: The Jersey Shore in the Eye of the Storm (Battle Ground, Washington: Pediment Publishing, 2012), 6.
} 


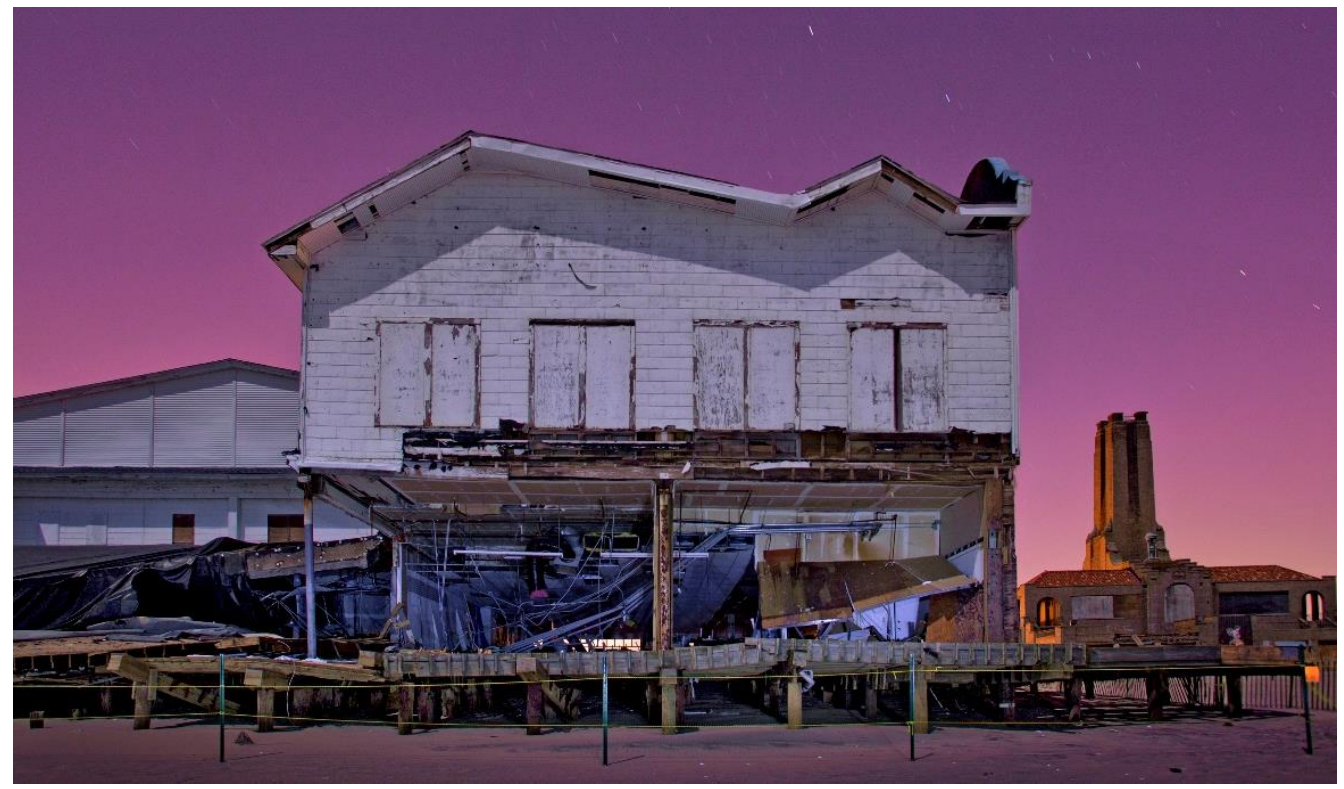

Damaged Ocean Grove boardwalk concession and the amusement steam power plant in Asbury Park. Photograph courtesy of Monmouth County resident Mike McLaughlin.

About 5 million residences lost electrical power across the region, including some 2.5-3 million in NJ. ${ }^{47}$ Power outages lasted for several weeks in many locations. Freeholder Gary Rich noted, "It wasn't just the people on the ocean, there were people that were further west. I think as citizens, we all participated in this. ${ }^{" 48}$ Serena DiMaso recalled in her Tracking Sandy oral history interview, "We were without power in Holmdel for 17 days ... We took a long time to come up."49 Jim Foley remembered, "It was at least 10 days [without power]. Probably closer to 12 or $14 \ldots$ I went and stood on line and bought gas cans to get gas to put in the car to drive out to west Jersey just to try to get food, because nobody had power, nobody had food." ${ }^{50}$ The Asbury Park Press

\footnotetext{
${ }^{47}$ Asbury Park Press, Sandy: The Jersey Shore in the Eye of the Storm (Battle Ground, Washington: Pediment Publishing, 2012), 4, 19; Pascack Valley Learning Center, Surviving Sandy: The Superstorm That Reshaped Our Lives (New York, New York: Ambient Funding, 2013), 110.

${ }^{48}$ Oral history interview with Gary Rich, interviewed by Melissa Ziobro, Freehold, NJ, 29 August 2017, property of the Monmouth County Historical Association.

${ }^{49}$ Oral history interview with Serena DiMaso, interviewed by Melissa Ziobro, Freehold, NJ, 29 August 2017, property of the Monmouth County Historical Association.

${ }^{50}$ Oral history interview with Jim Foley, interviewed by Melissa Ziobro, Long Branch, NJ, 8 August 2017, property of the Monmouth County Historical Association.
} 
reported some 2,500 light poles snapped. ${ }^{51}$ The NJ Public Service Electric and Gas (PSE\&G) Company estimated that 48,000 trees had to be removed or trimmed in order to restore power. Crews from across the country flocked to the state to help. Breaks in natural gas lines, occurring as a result of the storm, caused fires in some locations, resulting in the destruction of many residences. Power and gas line repairs were estimated at roughly $\$ 1$ billion and repairs to the waste, water and sewer services were estimated to cost about $\$ 3$ billion. Acute fuel shortages and power outages at gas stations caused gas lines to grow and panic to creep in. Gas rationing was temporarily implemented. ${ }^{52}$

On October 30, then- President Barack Obama declared that a major disaster existed in the State of NJ. This declaration made certain assistance requested by Governor Chris Christie available to affected individuals and households in Atlantic, Cape May, Essex, Hudson, Middlesex, Monmouth, Ocean, and Union Counties. This declaration also made debris removal and emergency protective measures available to State and eligible local governments and certain private nonprofit organizations on a cost-sharing basis in these counties. Finally, this declaration made Hazard Mitigation Grant Program assistance requested by the Governor available for hazard mitigation measures statewide. ${ }^{53}$

President Obama visited the state on October 31 to tour devastated areas (to include flying over Monmouth County). Republican Governor Christie later received criticism from those who claim he welcomed President Obama too warmly and that display somehow helped Obama win-

\footnotetext{
${ }^{51}$ Asbury Park Press, Sandy: The Jersey Shore in the Eye of the Storm (Battle Ground, Washington: Pediment Publishing, 2012), 19.

${ }^{52}$ Hong K. Kim, Mai Takematsu, Rana Biary, Nicholas Williams, Robert S. Hoffman, and Silas W. Smith, "Epidemic Gasoline Exposures Following Hurricane Sandy," Prehospital and Disaster Medicine (2013) 28 (6): 58691; Monmouth University Polling Institute, "Sandy’s Impact on NJ," 10 December 2012, https://www.monmouth.edu/polling-institute/reports/monmouthpoll_nj_121012/.

53 “NJ - Hurricane Sandy FEMA-4086-DR,” FEMA.gov, accessed 2 December 2018, https://www.fema.gov/medialibrary-data/20130726-1859-25045-4290/dhs_ocfc_pda_report_fema 4086_dr_nj_expedited_pdf.
} 
re-election against Republican opponent Mitt Romney on November 6. Christie has maintained, "I will put the interest, the fate, the safety of my people every day ahead of politics. Every day."54

\section{Community Efforts}

In the wake of Sandy, everyday people from around the country mobilized to help those impacted by the Storm. These efforts augmented the local, county, state, and federal responses. One FEMA report shows that 507 volunteer organizations participated in the recovery effort in NJ and 166,598 volunteers contributed 951,731 hours helping with flood debris cleanup, home repairs and reconstruction, as well as providing short-term needs, such as food, clothing and shelter assistance, and counseling services. Monolith non-profits like the Red Cross coordinated some non-governmental relief efforts, but many grassroots organizations also emerged and proved tremendously successful at fundraising, collecting supplies, and assembling volunteers. Many locals felt more comfortable dealing with these homegrown organizations, questioning how much of their donations to behemoths like the Red Cross actually reached those in need. A few notable Monmouth County based aid organizations included Sea Bright Rising and The Monmouth County Long-Term Recovery Group. ${ }^{55}$

Serena DiMaso noted, “It wasn't about who you worshiped or what color your skin was, it was about helping a community. I'm hoping that people remember that most of all because especially now, in all this turmoil, and everybody's worried about crazy stuff. It's really about being people first and taking care of each other. If you forget that, then society's lost. I think that's the biggest lesson from Sandy that we need to remember." A December 2012 Monmouth University poll showed that the storm left most residents with similarly positive feelings about

\footnotetext{
${ }^{54}$ Zeke J. Miller, “Christie: Obama 'Hug' Never Happened," TIME, 4 February 2016, http://time.com/4207368/chrischristie-barack-obama-hug/.

${ }_{55}$ Federal Emergency Management Agency, "When Disaster Strikes, Volunteer Efforts are Crucial," 23 August 2013, https://www.fema.gov/es/node/222905.
} 
their fellow NJ residents. Three in four (75\%) said Sandy brought out the best in people compared to just $12 \%$ who say the storm brought out the worst in people. Nearly 6 in 10 residents (57\%) reported that they personally donated food, clothing, or supplies; $43 \%$ donated money to a Sandy relief fund; $29 \%$ hosted displaced friends or family members in their home; and $25 \%$ volunteered their time to help with recovery or cleanup efforts. The poll asked state residents to rate how well nine different groups responded to the storm and its aftermath - and all came out with more positive than negative evaluations. Police and first responders were the recognized heroes $-79 \%$ of residents gave them a positive rating, including $47 \%$ who rated them as excellent and $32 \%$ as good. Just $10 \%$ said they did an only fair or poor job. The utility crews who hit the streets also received widespread praise from $71 \%$ of $\mathrm{NJ}$ residents, while just $21 \%$ gave the crews a negative rating. "There appears to be a strong consensus that $\mathrm{NJ}$ residents really pulled together to handle this unprecedented situation," said Patrick Murray, director of the Monmouth University Polling Institute. ${ }^{56}$ It must be noted, however, that the Monmouth County Prosecutor's Office established a task force to help Hurricane Sandy victims who fell prey to unscrupulous contractors. ${ }^{57}$

\section{Rebuilding}

"Stronger than the Storm" became a rallying cry that buoyed the spirits of many Monmouth County residents, but "restoring the shore" was easier said than done. The Storm moved through the state by October 30, but power remained out in many places for weeks. The most devastated areas were sealed off by police, with even residents having limited access. Halloween was postponed by gubernatorial decree. Election officials scurried to ensure everyone who wanted to

\footnotetext{
${ }^{56}$ Monmouth University Polling Institute, "Sandy’s Impact on NJ," 10 December 2012, https://www.monmouth.edu/polling-institute/reports/monmouthpoll_nj_121012/.

${ }^{57}$ Monmouth County Prosecutors' Office, "Monmouth County Prosecutor Launches County-Wide Task Force To Combat Contractor Fraud Against Superstorm Sandy Victims," 6 February 2013, http://www.visitmonmouth.com/Documents/29/02.06.Sandy.Fraud.release.doc.
} 
could vote in the presidential election on November 6. An early snowstorm dumped several inches of snow on the state on November 7-8, halting relief efforts, prompting fresh evacuations and exacerbating power outages. ${ }^{58}$ Governor Chris Christie was quoted as saying “... I’m waiting for the locusts and pestilence next." ${ }^{, 59}$ Many schools, from kindergarten through college, stayed closed while awaiting power or repairs. Some students ultimately resumed classes outside their school districts. Union Beach Memorial students, for example, attended St. Catherine's School in Middletown, Central School in Keyport, and Holy Family School in Hazlet. ${ }^{60}$

In the weeks, months, and years after Sandy hit, those impacted by the storm, from homeowners, to business owners, to municipalities, had to decide on their paths forward. Could flooded structures be dried? Did they need to be gutted lest mold sicken inhabitants? Could the most devastated areas be rebuilt? If rebuilding, what, if anything, might be done to help properties better withstand future storms? What might municipalities, the county, the state, the federal government, and insurance companies require of rebuilding efforts? Should structures be raised? How high? And where would all the money for this come from? Answering these questions often proved a long and onerous process. ${ }^{61}$

While environmentalists might question the sustainability of building along the coast, bays, and rivers, these properties represent huge emotional and economic value. Most people wanted to get back into their homes as quickly as possible to return to some sense of normalcy. Practically

\footnotetext{
${ }^{58}$ Barbara Goldberg, "Hurricane Sandy: Halloween postponed for millions of kids," Christian Science Monitor, 31 October 2012, https://www.csmonitor.com/USA/Latest-News-Wires/2012/1031/Hurricane-Sandy-Halloweenpostponed-for-millions-of-kids; Oral history interview with Joe Barris, interviewed by Melissa Ziobro, Freehold, NJ, 18 July 2017, property of the Monmouth County Historical Association.

${ }^{59}$ MaryAnn Spoto, “Gov. Christie warns about new power outages as nor'easter hits Jersey Shore,” NJ Advance Media, 7 November 2012, https://www.nj.com/news/index.ssf/2012/11/as_noreaster_hits_jersey_shore.html.

${ }^{60}$ Federal Emergency Management Agency, “One Year Later: NJ Schools Hit Hard, But Most Rebuild Quickly,” 1 October 2013, https://www.fema.gov/es/node/264227.

${ }^{61}$ Federal Emergency Management Agency (FEMA) Mitigation Assessment Team, "Recovery Advisories and Fact Sheets for Hurricane Sandy," accessed 1 December 2018, https://www.fema.gov/media-librarydata/1386072313670-21f4b31c1ebd7c79cc28664649fc90bb/Sandy_MAT_AppC_508post2.pdf.
} 
speaking, towns and businesses quickly turned an eye towards the 2013 tourist season. How quickly could the state restore the shore? A December 2012 Monmouth University poll showed that nearly half of NJ residents (47\%) felt it very important to repair damaged areas of the Jersey Shore in time for the summer 2013 tourist season. Among shore county residents, more than 6 in $10(62 \%)$ felt it very important. The same poll showed that the vast majority of NJ residents supported using state tax dollars to assist with storm recovery, except when it came to subsidizing private second homeowners down the shore. ${ }^{62}$

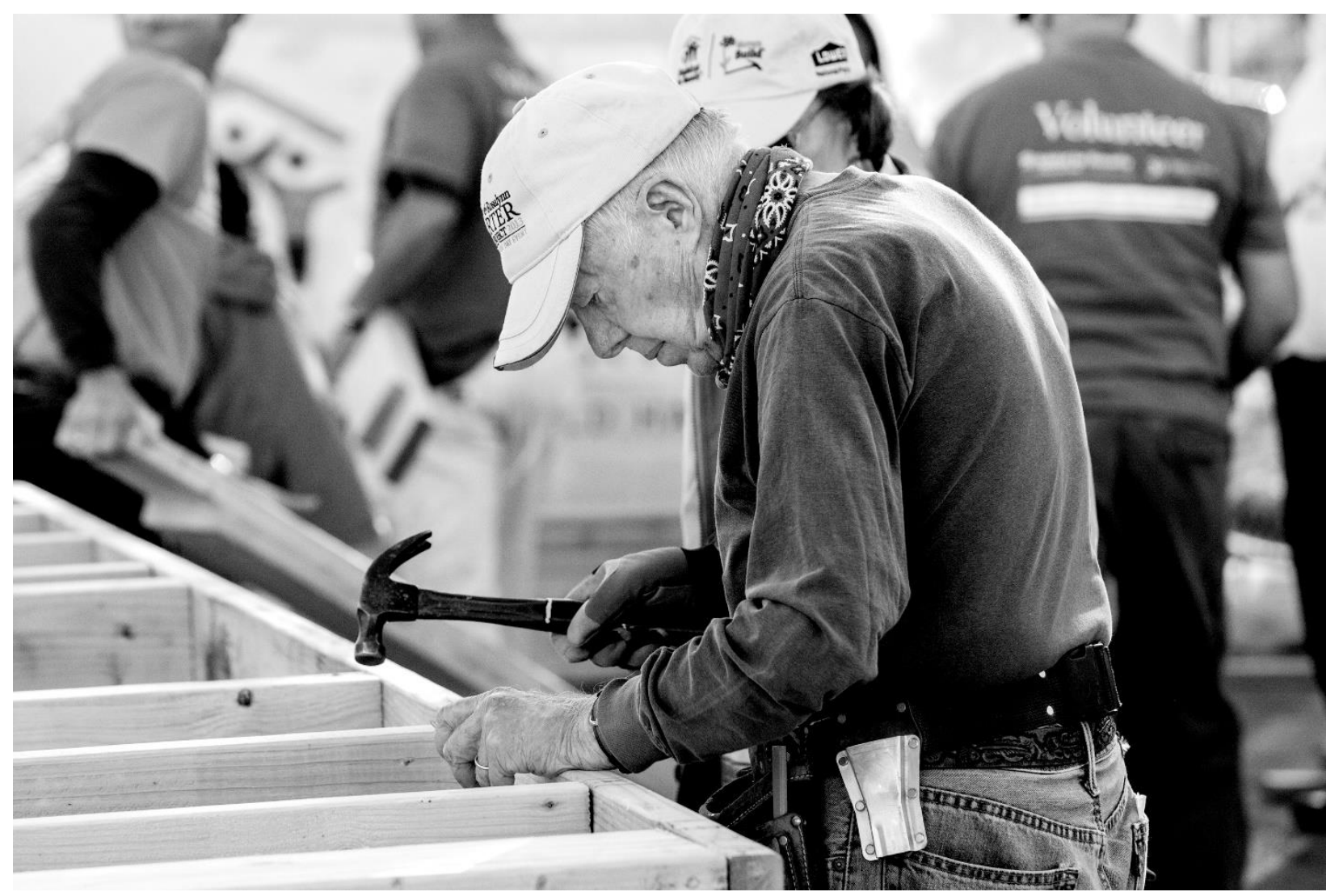

Former US President Jimmy Carter at work with Habitat for Humanity in Union Beach, 12 October 2013. Photograph courtesy of Monmouth County resident Mike McLaughlin.

\footnotetext{
${ }^{62}$ Monmouth University Polling Institute, "Sandy's Impact on NJ," 10 December 2012, https://www.monmouth.edu/polling-institute/reports/monmouthpoll_nj_121012/.
} 


\section{The Future}

While many are back in their homes and most businesses have re-opened their doors, Monmouth County's Sandy story is still unfolding. As Freeholder Lillian Burry noted in her Tracking Sandy oral history interview, "the results they have lingered on for a number of years, and in some instances, some people still aren't comfortably back to where they were." ${ }^{63}$ Not everyone has recouped their financial losses. Some never will. Precious family heirlooms have been lost forever. Confusion has left some who received Sandy aid actually owing money to the government, a situation often dubbed "clawback." ${ }^{64}$ Communities are still actively debating how to secure their shorelines for the long term.

Dr. Amy Williams noted in her Tracking Sandy oral history interview, “That's one of my biggest fears, that people will forget." ${ }^{65}$ So, is it important that we remember Sandy? As you might have gleaned, the Monmouth County Historical Association believes that it is. Tony MacDonald, Director of Monmouth University's Urban Coast Institute agrees, asserting “I think a project like this is fantastic, to actually remind people that this is something that can happen again and maybe with more frequency..." ${ }^{66}$ It's not just about commiserating with those who lost so much, but, as Sheriff Shaun Golden noted in his Tracking Sandy interview, “It's preparedness, preparedness, preparedness- and planning. What will your family do if this happens, and we hate saying for a

\footnotetext{
${ }^{63}$ Oral history interview with Lillian Burry, interviewed by Melissa Ziobro, Freehold, NJ, 29 August 2017, property of the Monmouth County Historical Association.

64 "6 Years After Sandy, Booker, Murphy, Pallone Praise Menendez, Celebrate Success and Urge Congress to Pass Menendez's Flood Insurance Reform Bill," 29 October 2018, https://www.menendez.senate.gov/news-andevents/press/6-years-after-sandy-booker-murphy-pallone-praise-menendez-celebrate-success-and-urge-congress-topass-menendezs-flood-insurance-reform-bill.

${ }^{65}$ Oral history interview with Dr. Amy Williams, interviewed by Melissa Ziobro, Manchester, NJ, 21 August 2017, property of the Monmouth County Historical Association.

${ }^{66}$ Oral history interview with Tony MacDonald, interviewed by Melissa Ziobro, West Long Branch, NJ, 10 July

2017, property of the Monmouth County Historical Association.
} 
hurricane, it's for any emergency. What will your family do?"67 Reminding ourselves that emergencies happen can, hopefully, inspire us to stay vigilant, to stay prepared.

So what can Monmouth County residents do to prepare for future emergencies? As discussed, many structures have been raised to in attempt to avoid future flooding. ${ }^{68}$ More important than saving property, though, is saving lives. Consider where you might shelter if you need to leave your home, no matter what the reason. Have an emergency kit with flashlights, batteries, food, and water. Know your evacuation zone, so that you can react to emergencies in a timely fashion. As Sheriff Golden notes, "Hope is not a plan. We say this, not just for Sandy, it's for really any application. You can have an overturned tanker chlorine truck right now on any of the major arteries that come through Monmouth County and what is your family going to do when we ask them to evacuate from that zone?"

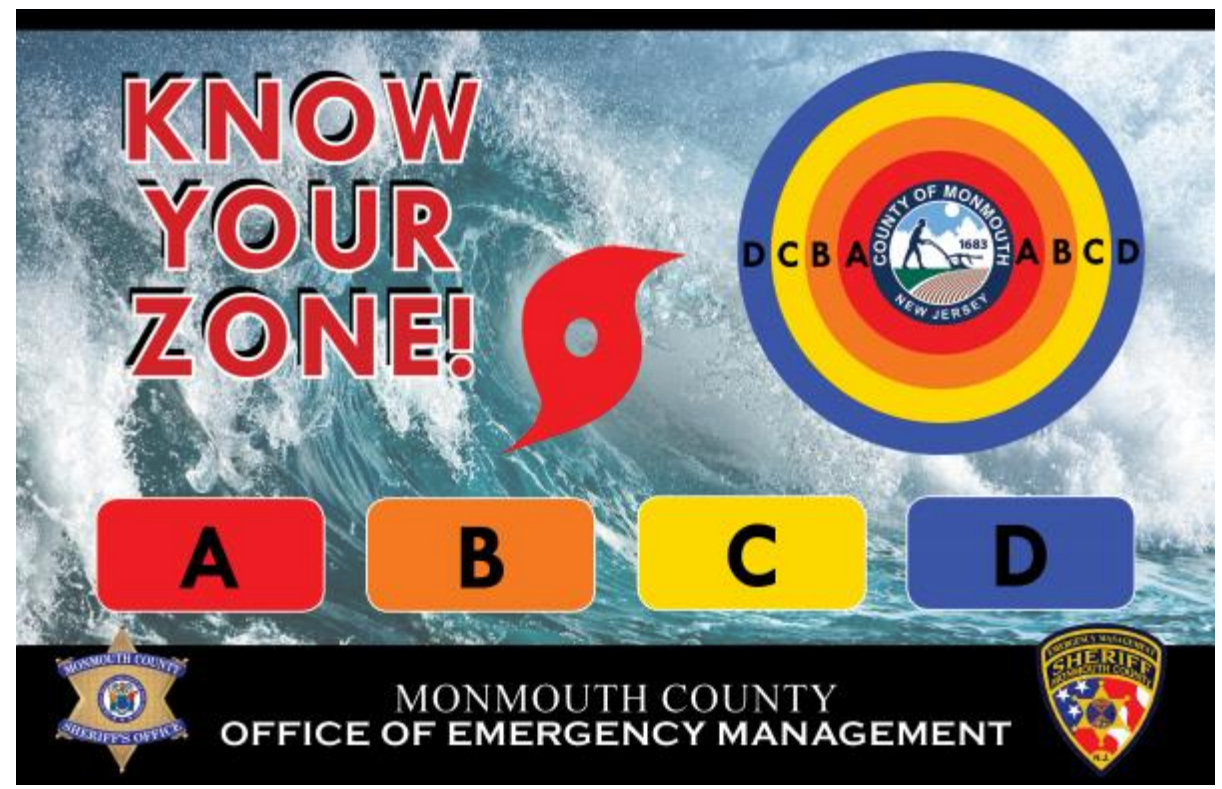

“Know Your Zone" graphic, courtesy of the Monmouth County Sheriff's Office. Learn more, and, if in Monmouth County, find your zone, here.

\footnotetext{
${ }^{67}$ Oral history interview with Shaun Golden, interviewed by Melissa Ziobro, Freehold, NJ, 1 August 2017, property of the Monmouth County Historical Association.

${ }^{68}$ Joseph Dobrian, “Hurricane Sandy” Journal of Property Management (2013) 78 (4): 28-32.

${ }^{69}$ Oral history interview with Shaun Golden, interviewed by Melissa Ziobro, Freehold, NJ, 1 August 2017, property of the Monmouth County Historical Association; Monmouth County Sheriff's Office, "Know Your Zone," accessed 3 December 2018, https://www.mcsonj.org/knowyourzone/.
} 
A February 2013 survey by the Monmouth University Polling Institute shows that about half of NJ's coastal residents (49\%) expect that a similar storm will occur sometime in the next ten years. Only $26 \%$ say Sandy was a once in a lifetime event. ${ }^{70}$ Many wonder if changes in our climate mean we will see stronger storms, more frequently. Others, like Dr. Amy Williams, note that sea level rise might mean that even the "usual" storms cause catastrophic flooding in the future. Williams noted, "My fear is that with climate change our patterns in our ocean and the patterns of our atmospheric pressure zones are going to change and so instead of a lot of storms going towards the Gulf of Mexico they may end up changing and coming up this way."71 Tony MacDonald, too, urges caution, saying, "A couple things people misunderstand is, with the hundred-year storm, is, that every year you have a $1 \%$ chance. It's not that they occur every hundred years." 72 One thing we do know? There will never be another Hurricane Sandy, literally speaking. The World Meteorological Organization's hurricane committee retired "Sandy" from the official list of Atlantic Basin tropical cyclone names in 2013 "because of the extreme impacts it caused from Jamaica and Cuba to the Mid-Atlantic US in October 2012.",73

Melissa Ziobro is currently the Specialist Professor of Public History at Monmouth University in West Long Branch, NJ, teaching courses to include Introduction to Public History, Oral History, and Museums and Archives Management. Her service to the University includes coordinating the Monmouth Memories Oral History Program and her Department's social media and newsletter. Melissa serves on the Executive Board of Oral History in the Mid-Atlantic Region;

\footnotetext{
${ }^{70}$ Monmouth University Polling Institute, “Superstorm Sandy Survey: Ipmact on NJ Coastal Residents,” February 2013, https://www.monmouth.edu/polling-institute/documents/monmouthpoll_njsandycoast_050713.pdf/.

${ }^{71}$ Oral history interview with Dr. Amy Williams, interviewed by Melissa Ziobro, Manchester, NJ, 21 August 2017, property of the Monmouth County Historical Association.

${ }^{72}$ Oral history interview with Tony MacDonald, interviewed by Melissa Ziobro, West Long Branch, NJ, 10 July 2017, property of the Monmouth County Historical Association.

73 "Sandy retired from list of Atlantic Basin tropical cyclone names," National Oceanic and Atmospheric Administration.gov, 11 April 2013, http://www.noaa.gov/sandy-retired-list-atlantic-basin-tropical-cyclone-names
} 
and as a Trustee of the Parker Homestead in Little Silver, NJ and the Ocean County Historical Society. She has worked with public history organizations such as the Monmouth County Park System, InfoAge Science History Learning Center and Museum, Monmouth County Historical Association, Monmouth County Historical Commission, Middlesex County Office of Culture and Heritage, National Guard Militia Museum of NJ, and more. She served as a command historian at the U.S. Army Communications-Electronics Command, Fort Monmouth, NJ from 2004-2011. The author would like to thank the Monmouth University interns who assisted with the "Tracking Sandy" exhibit: Connie Jara, Mara Manzar, and Maggie Smith; as well as the following individuals who reviewed versions of this text: Cynthia Scott (Monmouth County Sheriff's Office); Mindy Voss (NJ Sea Grant Consortium); Dr. Amy Williams, (Stevens Institute of Technology/NJ Sea Grant Consortium), and other blind peer reviewers. Thanks, too, are due to exhibit designer Stain Cain, MCHA Board President Linda Bricker, and then MCHA Acting Executive Director Chuck Jones. Lastly, thanks to MCHA Curator Joe Hammond for allowing a guest curator to use his Washington Gallery! 